\title{
THE
}

\section{Amino acid isotope discrimination factors for a carnivore: physiological insights from leopard sharks and their diet}

\author{
John P. Whiteman \\ Sora L. Kim \\ Kelton W. McMahon \\ University of Rhode Island, kelton_mcmahon@uri.edu \\ Paul L. Koch \\ Seth D. Newsome
}

Follow this and additional works at: https://digitalcommons.uri.edu/gsofacpubs

The University of Rhode Island Faculty have made this article openly available.

Please let us know how Open Access to this research benefits you.

This is a pre-publication author manuscript of the final, published article.

Terms of Use

This article is made available under the terms and conditions applicable towards Open Access Policy Articles, as set forth in our Terms of Use.

\section{Citation/Publisher Attribution}

Whiteman JP, Kim SL, McMahon KW, Koch PL, Newsome SD (2018) Amino acid isotope discrimination factors for a carnivore: physiological insights from leopard sharks and their diet. Oecologia 188:977-989 Available at: https://doi.org/10.1007/s00442-018-4276-2

This Article is brought to you for free and open access by the Graduate School of Oceanography at DigitalCommons@URI. It has been accepted for inclusion in Graduate School of Oceanography Faculty Publications by an authorized administrator of DigitalCommons@URI. For more information, please contact digitalcommons-group@uri.edu. 
2 Amino acid isotope discrimination factors for a carnivore: physiological insights from leopard

3 sharks and their diet

4

5 Authors $^{\dagger}$

6 John P. Whiteman ${ }^{1 *}$, Sora L. Kim² ${ }^{2}$ Kelton W. McMahon ${ }^{3}$, Paul L. Koch ${ }^{4}$, Seth D. Newsome ${ }^{1}$

7

8 Affiliations

$9 \quad{ }^{1}$ Department of Biology, University of New Mexico, Albuquerque, New Mexico, 87131, USA

$10{ }^{2}$ Department of Life and Environmental Sciences, University of California, Merced, California, 1195343, USA

$12{ }^{3}$ Graduate School of Oceanography, University of Rhode Island, Narragansett, Rhode Island, 13 02882, USA

$14{ }^{4}$ Department of Earth and Planetary Sciences, University of California, Santa Cruz, California, 1595064, USA

16

$17 *$ Corresponding author; jwhiteman@unm.edu; 307.760.1973

${ }^{\dagger}$ Contributions: SLK and PLK formulated the idea, SLK conducted the feeding experiment, all authors contributed to the development of the compound-specific stable isotope analyses, JPW, SLK, and SDN performed laboratory analyses, all authors interpreted the data, and JPW led the collaborative writing of the manuscript. 


\section{Abstract}

Stable isotopes are important ecological tools because the carbon and nitrogen isotopic composition of consumer tissue reflects the diet. Measurements of isotopes of individual amino

21 acids can disentangle the effects of consumer physiology from spatiotemporal variation in

22 dietary isotopic values. However, this approach requires knowledge of assimilation patterns of 23 dietary amino acids. We reared leopard sharks (Triakis semifasciata) on diets of squid (Loligo 24 opalescens; 1250 days; control sharks) or squid then tilapia (Oreochromis sp.; switched at 565 25 days; experimental sharks) to evaluate consumer-diet discrimination factors for amino acids in 26 muscle tissue. We found that control sharks exhibited lower nitrogen isotope discrimination 27 factors $\left(\Delta^{15} \mathrm{~N}\right)$ than most previous consumer studies, potentially because of urea recycling.

28 Control sharks also had large carbon isotope discrimination factors $\left(\Delta^{13} \mathrm{C}\right)$ for three essential 29 amino acids, suggesting microbial contributions or fractionation upon assimilation. Compared to 30 controls, experimental sharks exhibited higher $\Delta^{13} \mathrm{C}$ values for four amino acids and $\Delta^{15} \mathrm{~N}$ values 31 for seven amino acids, corresponding with differences between diets in $\delta^{13} \mathrm{C}$ and $\delta^{15} \mathrm{~N}$ values.

32 This suggests that not all amino acids in experimental sharks had reached steady state, contrary 33 to the conclusion of a bulk isotope study of these sharks. Our results imply that 1) the magnitude 34 of a shift in dietary $\delta^{13} \mathrm{C}$ and $\delta^{15} \mathrm{~N}$ values temporarily influences the appearance of discrimination 35 factors; 2) slow turnover of amino acid isotopes in elasmobranch muscle precludes inferences 36 about seasonal dietary changes; and 3) elasmobranch discrimination factors for amino acids may 37 be affected by urea recycling and microbial contributions of amino acids.

\section{Key words:}

40 elasmobranchs, fractionation, growth, microbes, urea 


\section{Introduction}

43 Understanding the foraging ecology of upper trophic level consumers, such as elasmobranchs, is

44 important because they can profoundly influence ecosystems (Young et al. 2015; Bird et al.

45 2018). Researchers often assess elasmobranch diet by analyzing the stable carbon $\left(\delta^{13} \mathrm{C}\right)$ and

46 nitrogen $\left(\delta^{15} \mathrm{~N}\right)$ isotope values of their bulk tissue (e.g., muscle), which reflect the isotopic

47 composition of the food they assimilate (Hussey et al. 2011; Shiffman et al. 2012). However,

48 temporal and spatial variation in $\delta^{13} \mathrm{C}$ and $\delta^{15} \mathrm{~N}$ values of producers at the base of the food web

49 can confound interpretations about food assimilation (Vokhshoori and McCarthy 2014; Lorrain

50 et al. 2015). Analysis of the isotopic composition of individual amino acids is a potentially useful

51 technique to resolve these confounding factors because amino acid metabolism provides a

52 context for data interpretation (e.g., for many consumers, certain amino acids can only be

53 obtained from the diet while others can be synthesized de novo). However, this approach requires

54 understanding amino acid discrimination factors $(\Delta)$, which are offsets in amino acid $\delta^{13} \mathrm{C}$ and

$55 \delta^{15} \mathrm{~N}$ values between consumers and their diet (e.g., $\Delta^{15} \mathrm{~N}=\delta^{15} \mathrm{~N}_{\text {consumer }}-\delta^{15} \mathrm{~N}_{\text {diet }}$ ). These

56 discrimination factors in sharks may differ from those reported for other organisms because of

57 their unusual physiology as carnivorous ectotherms who retain urea for use as an osmolyte

58 (Hussey et al. 2010; Hoen et al. 2014; Kim et al. 2012b).

Initial biological applications of stable isotope analysis often used the simplifying

60 assumption that dietary nutrients were assimilated as homogenous pools of carbon and nitrogen,

61 from which macromolecules could be synthesized (Martínez del Rio et al. 2009). However, some

62 dietary macromolecules are assimilated intact. For instance, animals cannot synthesize essential

63 amino acids (e.g., threonine, phenylalanine, lysine, isoleucine, leucine, valine) and thus their 
64 carbon skeletons are routed directly into endogenous tissue from dietary protein, leading to

65 relatively small carbon discrimination factors (Howland et al. 2003; Jim et al. 2006). As a result,

66 the $\delta^{13} \mathrm{C}$ values of essential amino acids in consumer tissues reflect those of primary producers in

67 a food web. In contrast, non-essential amino acids (e.g., glycine, serine, alanine, aspartic acid,

68 glutamic acid, tyrosine) can be synthesized de novo by animals, potentially from non-protein

69 carbon sources (e.g., lipids and carbohydrates). Carbon isotopic discrimination factors for these

70 amino acids, therefore, may be larger and more variable, reflecting complex biochemical

71 pathways (McMahon et al. 2010; Newsome et al. 2014).

72

Nitrogen isotope dynamics for amino acids do not necessarily align with the categories of

73 essential and non-essential. Instead, some amino acids retain their amine nitrogen through

74 metabolic processing. These "source amino acids" (e.g., phenylalanine, lysine, tyrosine; and in

75 some organisms, glycine and serine) exhibit relatively small isotope discrimination factors,

76 meaning they preserve the $\delta^{15} \mathrm{~N}$ values of primary producers across a food web (Chikaraishi et al.

77 2007; McMahon and McCarthy 2016). In contrast, "trophic amino acids" (e.g., alanine, aspartic

78 acid, glutamic acid, isoleucine, leucine, valine) routinely exchange amine nitrogen with a

79 consumer's internal nitrogen pool after absorption, leading to large discrimination factors that

80 cause $\delta^{15} \mathrm{~N}$ to increase with trophic level (Nielsen et al. 2015; O'Connell 2017). The magnitude

81 of discrimination factors is also influenced by nitrogen use efficiency (Cantalapiedra-Hijar et al.

82 2017) and nutritional composition of the diet. Diets with amino acid compositions more similar

83 to the tissue of the consumer often result in smaller discrimination factors, for both bulk tissue

84 and individual amino acids (Robbins et al. 2005; Florin et al. 2011; McMahon et al. 2015). Total

85 dietary protein also affects bulk discimination factors, although contradictory trends have been

86 reported with high protein correlating with both increased (Kelly and Martínez del Rio 2010) and 
87 decreased discimination (Hughes et al. 2018). Thus, discrimination factors for bulk tissue and

amino acids of consumers can be influenced by their diet, physiology, and trophic level.

$$
\text { Discrimination factors are often assessed with controlled feeding experiments using }
$$
captive animals. Such experiments must also consider isotopic turnover rate, which is the pace of incorporation of dietary carbon and nitrogen into consumer biomass during tissue addition (i.e., accretion during growth) or replacement (i.e., maintenance). Turnover rate is influenced by metabolic rate and body size, among other factors (Martínez del Rio and Carleton 2012; Vander Zanden et al. 2015). Most elasmobranchs are ectotherms, which tend to exhibit slow turnover rates (Vander Zanden et al. 2015), and sharks can take over a year for their bulk muscle tissue to reach a steady state with the isotopic composition of a new diet (Malpica-Cruz et al. 2012; Kim et al. 2012b). Importantly, incomplete turnover can cause discrimination factors to appear different than they would for an animal that has reached steady state (Fig. 1).

Here, we use a long-term feeding study to evaluate variations in carbon and nitrogen isotope discrimination factors for amino acids in muscle tissue from leopard sharks (Triakis semifasciata), an abundant predator in Pacific coastal waters of North America. Nine captive leopard sharks were fed squid (Loligo opalescens) for 565 days then divided into control and experimental groups (Kim et al. 2012a, b). For the subsequent 685 days, control sharks $(\mathrm{N}=3)$ continued eating squid while experimental sharks $(\mathrm{N}=6)$ were fed tilapia (Oreochromis sp.). Bulk tissue analysis of muscle samples collected at the end of the experiment indicated that $\delta^{13} \mathrm{C}$ and $\delta^{15} \mathrm{~N}$ of both control and experimental sharks had reached steady states with their respective diets (Kim et al. 2012a, b), although bulk $\Delta^{13} \mathrm{C}$ and $\Delta^{15} \mathrm{~N}$ differed between diets. Using the same set of muscle samples, here we test the fundamental assumptions that isotopic discrimination factors are 1) near zero for essential amino acids $\left(\Delta^{13} \mathrm{C}\right)$ and source amino acids $\left(\Delta^{15} \mathrm{~N}\right)$, and 2) 
110 larger than zero for non-essential amino acids $\left(\Delta^{13} \mathrm{C}\right)$ and trophic amino acids $\left(\Delta^{15} \mathrm{~N}\right)$. We also

111 test whether diet amino acid concentrations influenced discrimination factors. Finally, although

112 we expected that all amino acids in muscle from both groups of sharks had reached isotopic

113 steady states with their diets, we evaluated whether variation in discrimination factors was

114 suggestive of incomplete turnover. The results provide a framework for interpreting the

115 movement and foraging ecology of wild elasmobranchs using amino acid isotope data.

\section{Materials and Methods}

118 Feeding experiment and sampling. Details of husbandry, feeding, and sampling for this

119 controlled feeding study can be found in Kim et al. (2012a, b) and Zeichner et al. (2017). Briefly, 120 nine juvenile leopard sharks were caught in San Francisco Bay between August-December 2005 121 via otter trawl with the Marine Science Institute (Redwood City, CA) and housed at the Long 122 Marine Lab of the University of California, Santa Cruz throughout the experiment. Sharks were 123 kept in polyethylene tanks (1-2 individuals per tank; $2.3 \mathrm{~m}$ diameter and $1.2 \mathrm{~m}$ water depth) with 124 a continuous flow of filtered seawater from Monterey Bay. All sharks were fed three times per 125 week throughout the experiment; individuals sharing tanks were separated by a net for feeding. 126 All sharks (both the squid and tilapia fed) received 3-5\% of their body mass per day, which was 127 adjusted throughout the experiment. Every 2-3 weeks, total body length was measured and serial 128 sampling of tissue was performed for other studies (i.e., blood, muscle, and teeth). Hematocrit 129 values were periodically assessed as a measure of health. Starting on day 0 of the experiment 130 (13-January-2006) all individuals were fed a constant diet of squid. On day 565 (01-August131 2007), six individuals (in three tanks) were randomly switched to the experimental group and 132 thereafter fed tilapia (farm-raised in Taiwan) for a subsequent 685 days. The remaining three 
133 individuals in the control group continued to receive squid for the entire 1250 days. Squid and

134 tilapia were ordered in a single batch at the beginning of the experiment and portioned once per

135 month as whole squid or headless tilapia. On day 1250 (01-July-2009), all sharks were sacrificed

136 using MS-222 and muscle samples were collected. The present study only includes these shark

137 muscle samples collected at the end of the experiment. Samples of shark muscle, whole squid,

138 and headless tilapia were freeze-dried and stored in plastic bags until isotopic analysis. The care,

139 sampling, and sacrifice protocol for the sharks in this study was approved by the UC Santa Cruz

140 Chancellor's Animal Research Committee (CARC), in accordance with Institutional Animal

141 Care and Use Committee (IACUC) standards (permit \# Kochp0901).

142

143 Sample preparation and elemental and isotopic analyses. Bulk tissue measurements of $\delta^{13} \mathrm{C}$ and

$144 \quad \delta^{15} \mathrm{~N}$ values for all shark muscle samples (Table S1) and diet items were analyzed in Kim et al.

145 (2012a, b). Samples of squid and tilapia were analyzed for amino acid composition at the

146 University of Wyoming (WY, USA) Macromolecular Analysis Core on an AB Sciex TOF/TOF

1475800 mass spectrometer. Samples of muscle from control sharks were analyzed for amino acid

148 composition at the University of California, Santa Cruz (CA, USA) on a quadrupole gas

149 chromatograph-mass spectrometer (Agilent 7890A GC coupled to MS 5975B/EI); results were

150 reported in Kim and Koch (2012). We assumed that the amino acid composition of these muscle

151 samples from control sharks was representative of experimental sharks as well because muscle

152 amino acid composition is well-conserved among shark species (Chandrashekar and Deosthale

153 1993; Onodenalore and Shahidi 1996; Diniz and Martin 1997) and because individuals in both

154 groups ate consistently, grew in length, and had adequate hematocrit values throughout the

155 experiment, suggesting that there were no major physiological stressors. 
All other analyses were performed at the Center for Stable Isotopes at the University of

157 New Mexico (NM, USA). Two subsamples of squid and two subsamples of tilapia were weighed

158 into tin capsules $(\sim 0.5 \mathrm{mg})$ and analyzed for percent carbon and nitrogen on a Costech 4010

159 Elemental Analyzer. Other subsamples of squid and tilapia, as well as all shark muscle samples,

were lipid-extracted by soaking them three times with 2:1 chloroform:methanol ( 24 hours per

161 soak) then rinsing them four times with distilled water. Shark muscle samples were then

162 additionally soaked three times with distilled water (24 hours per soak) to remove urea (Kim and

163 Koch 2012). All samples were then freeze-dried for 24 hours.

Isotope analysis of individual amino acids followed Engel and Hare (1985) and Fantle et

165 al. (1999). Samples were weighed out to approximately $10-15 \mathrm{mg}$ and hydrolyzed in $1 \mathrm{ml}$ of $6 \mathrm{~N}$

$166 \mathrm{HCl}$ for 20 hours at $110^{\circ} \mathrm{C}$. During hydrolysis, glutamine was converted to glutamic acid and

167 asparagine was converted to aspartic acid. Hydrolyzed samples were dried under a stream of $\mathrm{N}_{2}$

168 gas then derivatized to N-trifluoroacetic acid isopropyl esters and resuspended in

169 dichloromethane. Samples were injected $(1 \mu 1)$ into a gas chromatograph (Thermo Scientific

170 Trace $1300 \mathrm{GC}$; column BPx5, $60 \mathrm{~m}$ ) for separation of amino acids, which were then combusted

171 to $\mathrm{CO}_{2}$ or reduced to $\mathrm{N}_{2}$ at $1000^{\circ} \mathrm{C}$ (Thermo Scientific GC Isolink II) and analyzed on an isotope

172 ratio mass spectrometer (Thermo Scientific Delta V Plus IRMS).

$173 \quad$ For each sample, we analyzed two injections for $\delta^{13} \mathrm{C}$ values (with a standard every fifth 174 injection) and three injections for $\delta^{15} \mathrm{~N}$ values (with a standard every fourth injection). SD for 175 multiple injections of the same sample averaged $0.16 \%$ (range $0.00-0.62$ ) for $\delta^{13} \mathrm{C}$ and $0.55 \%$ $176(0.05-1.92)$ for $\delta^{15} \mathrm{~N}$ values. Standards of pure amino acids of known isotopic composition 177 (Sigma-Aldrich Co.) had SDs for multiple injections that averaged $0.28 \%$ (0.00-1.21) for $\delta^{13} \mathrm{C}$ 
178 and $0.81 \%$ o $(0.00-1.69)$ for $\delta^{15} \mathrm{~N}$ values. Standardization of runs was achieved using intermittent

179 pulses of $\mathrm{CO}_{2}$ or $\mathrm{N}_{2}$ gases of known isotopic value.

To account for the addition of carbon and the kinetic isotope fractionation associated with

181 derivatization, $\delta^{13} \mathrm{C}$ values were corrected as follows:

$$
\delta^{13} \mathrm{C}_{\text {sample.underiv }}=\left(\delta^{13} \mathrm{C}_{\text {sample.deriv }}-\delta^{13} \mathrm{C}_{\text {standard.deriv }}+\left(\delta^{13} \mathrm{C}_{\text {standard.underiv }} \times P\right)\right) \times P^{-1}
$$

183 Here, $\delta^{13} \mathrm{C}_{\text {sample.underiv }}$ is the final, calculated value of the amino acid; $\delta^{13} \mathrm{C}_{\text {sample.deriv }}$ is the

184 measured value of the derivatized amino acid; $\delta^{13} \mathrm{C}_{\text {standard.underiv }}$ is the measured value of the un-

185 derivatized amino acid in the standard (previously assessed via elemental analyzer coupled with

186 isotope ratio mass spectrometry); and $P$ is the proportion of carbon in the amino acid from the

187 original sample. Correction of $\delta^{15} \mathrm{~N}$ values was less complex because derivatization does not add

188 exogenous nitrogen:

$$
\delta^{15} \mathrm{~N}_{\text {sample.underiv }}=\left(\delta^{15} \mathrm{~N}_{\text {sample.deriv }}+\left(\delta^{15} \mathrm{~N}_{\text {standard.deriv }}-\delta^{15} \mathrm{~N}_{\text {standard.underiv }}\right)\right)
$$

This method of analysis yields data on 13 amino acids. However, here we exclude stable isotope data from proline because its values are affected by co-elution with hydroxyproline.

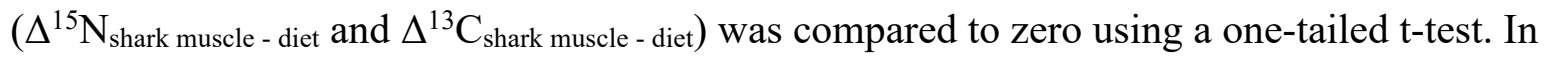
addition, amino acid discrimination factors were compared between control and experimental 195 sharks using a two-tailed t-test or if the data failed to exhibit normality (via the Shapiro-Wilk test), a Mann-Whitney rank test. To evaluate the influence of amino acid composition on

197 discrimination factors, linear regressions were analyzed in which the predictor variable was 198 amino acid imbalance (i.e., the mole percent of an amino acid in the diet minus the mole percent of that amino acid in shark muscle) and the response variable was the mean discrimination factor

200 for that amino acid (carbon or nitrogen) between sharks and their diet. In general, $\Delta^{13} \mathrm{C}$ values 
201 should be larger for non-essential than for essential amino acids and $\Delta^{15} \mathrm{~N}$ values should be larger

202 for trophic than for source amino acids. Thus, regression models were evaluated using all data;

203 using only non-essential amino acids for $\Delta^{13} \mathrm{C}$ values; and using only trophic amino acids for

$204 \Delta \Delta^{15} \mathrm{~N}$ values. Linear regressions were used to assess the relationship between 1) the difference

205 between diets in $\delta^{13} \mathrm{C}$ or $\delta^{15} \mathrm{~N}$ values, and 2) the difference in $\Delta^{13} \mathrm{C}$ or $\Delta^{15} \mathrm{~N}$ values between

206 sharks consuming each diet. Residual normality of regression models was assessed with the

207 Shapiro-Wilk test and potential outliers were evaluated with Cook's Distance score. The $\alpha$ value

208 was 0.05 for all tests. Statistical analyses were calculated in SigmaPlot 13.0.

209

210 Results

211 Comparisons of nutritional composition of diets. The control diet of squid and the experimental

212 diet of tilapia were relatively similar in nutrition. Mean C:N ratios of non-lipid-extracted samples

213 suggested that squid (3.7 $\pm 0.2 \mathrm{SD} ; n=2)$ was lower in fat than tilapia $(4.5 \pm 0.2 ; n=2)$. Using an

214 empirically-derived equation to convert $\mathrm{C}: \mathrm{N}$ ratios to percent lipid by mass for aquatic organisms

215 (equation 2 in Post et al. 2007), the squid diet was $6 \%$ fat ( $\pm 1 \%$ SD) and the tilapia diet was $12 \%$

216 ( $\pm 1 \% \mathrm{SD})$. The amino acid composition (mole percent) of squid, tilapia, and shark muscle

217 appeared to be similar (Table 1). Amino acid imbalances between shark muscle and diet items

218 did not correlate to amino acid discrimination factors for carbon or nitrogen (Table 2), with one

219 exception: the imbalance among non-essential amino acids correlated to $\Delta^{13} \mathrm{C}$ values for

220 experimental sharks. However, a high Cook's Distance score $(>1)$ suggested that serine was an

221 outlier in this model and after its removal, this correlation was not significant (Table 2). Bulk

222 isotope values of lipid-extracted diet samples, analyzed and presented in Kim et al. (2012b), 
223 differed for $\delta^{13} \mathrm{C}$ values (squid: $-18.5 \pm 0.5 \%$ o $\mathrm{SD}$, tilapia: $-23.2 \pm 0.9 \%$ ) and $\delta^{15} \mathrm{~N}$ values (squid:

$224 \quad 13.3 \pm 0.7 \%$, tilapia: $7.9 \pm 0.4 \%$ o.

226 Carbon isotope discrimination. Amino acids varied in $\delta^{13} \mathrm{C}$ values for squid, tilapia, and shark

227 muscle (Fig. 2a). Both experimental and control sharks exhibited a wide range of amino acid

228 discrimination factors (Fig. 2b), although several $\Delta^{13} \mathrm{C}$ patterns were similar between these two

229 groups. Among non-essential amino acids, both experimental and control sharks exhibited a

230 discrimination factor for serine that did not differ from zero. In contrast, both groups exhibited

231 large discrimination factors for the ketogenic amino acids (alanine, aspartic acid, glutamic acid,

232 tyrosine). Among essential amino acids, both experimental and control sharks showed no

233 discrimination for threonine but high discrimination for leucine and valine. Discrimination

234 factors for other amino acids differed between groups. One non-essential (glycine) and three

235 essential (phenylalanine, lysine, and isoleucine) amino acids had larger discrimination factors for

236 experimental sharks than for control individuals (Fig. 2b). The differences in $\Delta^{13} \mathrm{C}$ values

237 between experimental and control sharks correlated with the $\delta^{13} \mathrm{C}$ differences between their

238 respective diet items (tilapia and squid; Fig. 3a). Assuming that the control sharks were in a

239 steady state with their diet (see Discussion) and based on the similar nutrition of the two diets, it

240 is expected that the experimental sharks would eventually exhibit the same amino acid $\Delta^{13} \mathrm{C}$

241 values as control sharks. Thus, amino acids that did not differ in $\Delta^{13} \mathrm{C}$ between control and

242 experimental sharks either had similar $\delta^{13} \mathrm{C}$ values between diets or had turned over $\sim 100 \%$ of

243 their carbon pool in the experimental sharks. In contrast, the amino acids that differed in $\Delta^{13} \mathrm{C}$

244 between control and experimental sharks were calculated to have turned over $36-64 \%$ of their

245 carbon pool (Table 3). 
247 Nitrogen isotope discrimination. Amino acids varied in $\delta^{15} \mathrm{~N}$ values for squid, tilapia, and shark

248 muscle (Fig. 4a). For most source amino acids, $\delta^{15} \mathrm{~N}$ values were similar for squid, tilapia,

249 experimental shark muscle, and control shark muscle, resulting in relatively small amino acid

250 discrimination factors between diet and consumer (Fig. 4b). For both experimental and control

251 sharks, discrimination did not differ from zero for phenylalanine and median values were $<3 \%$ o

252 for lysine and tyrosine. Between groups, median $\Delta^{15} \mathrm{~N}$ values were similar for glycine (1-2\%o)

253 and dissimilar for serine (2\%o for experimental, $-5 \%$ for control). Discrimination factors for

254 threonine and for trophic amino acids were greater for the experimental group than for the

255 control group. For experimental sharks, trophic amino acids had a mean discrimination factor of

$2569.8 \%$ ( $( \pm 1.6 \mathrm{SD})$, while the mean for control individuals was 3.8\%o $( \pm 1.4)$. The discrimination

257 factor for threonine was less for experimental sharks (median of -11\%) than for control sharks

258 (median of $-8 \%$ ). The differences in $\Delta^{15} \mathrm{~N}$ values between experimental and control individuals

259 correlated with $\delta^{15} \mathrm{~N}$ differences between their respective diet items (tilapia and squid; Fig. 3b).

260 The Cook's Distance score indicated that threonine was a potential outlier in this relationship;

261 however, regression statistics were almost unchanged after its removal $\left(P<0.01, \mathrm{R}^{2}=0.95\right)$.

262 Similar to carbon, it is expected that the experimental sharks would eventually exhibit the same

263 amino acid $\Delta^{15} \mathrm{~N}$ values as control sharks. Thus, amino acids that did not differ in $\Delta^{15} \mathrm{~N}$ between

264 control and experimental sharks either had similar $\delta^{15} \mathrm{~N}$ values between diets or had turned over

$265 \sim 100 \%$ of their nitrogen pool in the experimental sharks. In contrast, the amino acids that

266 differed in $\Delta^{15} \mathrm{~N}$ between control and experimental sharks were calculated to have turned over

$267 \quad 17-47 \%$ of their nitrogen pool (Table 3). 


\section{Discussion}

270 The stable isotope analysis of individual amino acids has created new opportunities to study the

271 foraging ecology of upper trophic level consumers, such as elasmobranchs. However, application

272 of this technique requires careful calibration of isotopic discrimination factors of amino acids,

273 via controlled feeding experiments if possible. For many amino acids in our study, $\Delta^{13} \mathrm{C}$ and

$274 \Delta \Delta^{15} \mathrm{~N}$ values were larger for experimental sharks (fed squid for 565 days then switched to tilapia

275 for 685 days) than for control sharks (fed squid for the entire 1250 days). This result was

276 surprising because we expected that by the experiment's end, experimental individuals would be

277 in a steady state with their new diet (Kim et al. 2012a, b) and therefore they would exhibit

278 similar amino acid discrimination factors as control individuals for both carbon and nitrogen.

279 Although discrimination factors can be influenced by dietary nutritional composition, this

280 factor was unlikely to have caused differences between experimental and control sharks, for two

281 reasons. First, protein quality appeared to be relatively high for both diets; poor quality is

282 indicated by dissimilarity in amino acid composition between consumer tissue and food

283 correlating with large discrimination factors (McMahon et al. 2015). Here, we found no such

284 correlations for sharks consuming either diet. Second, protein content was likely high for both

285 diet items, consistent with their relatively low C:N ratios. Nutritional assessments show that

286 protein, carbohydrate, and lipid content for squid average $78 \%, 15 \%$, and $7 \%$ and for tilapia

287 average $92 \%, 0 \%$, and $8 \%$ (USDA). The difference in carbohydrates did not appear to affect

288 amino acid metabolism; if it had, we would have expected control sharks to exhibit larger $\Delta^{13} \mathrm{C}$

289 values because of the greater availability of a non-protein carbon source for amino acid synthesis

290 (Newsome et al. 2011), which we did not observe. Instead, we suggest that the primary cause of

291 differences in amino acid discrimination factors between experimental and control sharks was 
292 incomplete turnover for some amino acids in the experimental treatment, as discussed in detail 293 below.

Experimental sharks. Compared to control sharks, experimental individuals had greater $\Delta^{13} \mathrm{C}$

296 values for one non-essential (glycine) and three essential amino acids (Fig. 2; phenylalanine,

297 lysine, isoleucine) and greater $\Delta^{15} \mathrm{~N}$ values for all six trophic amino acids (alanine, asx, glx,

298 isoleucine, leucine, valine) and threonine (Fig. 4). These differences in discrimination factors

299 could be caused by amino acids in the muscle of experimental sharks having not yet reached a

300 steady state with their new diet. This explanation is supported by the facts that 1) the new diet

301 was lower in $\delta^{13} \mathrm{C}$ and $\delta^{15} \mathrm{~N}$, which would lead to the observed direction of change in amino acid

302 discrimination factors, and 2) the magnitude of difference in $\delta^{13} \mathrm{C}$ and $\delta^{15} \mathrm{~N}$ values between diets

303 predicted the amount by which the amino acid discrimination factor increased after the diet

304 switch. Larger offsets between diet and consumer $\delta^{13} \mathrm{C}$ or $\delta^{15} \mathrm{~N}$ values make it easier to discern a

305 lack of steady state conditions, whereas smaller offsets (especially those that are similar in

306 magnitude to analytical uncertainty) can create a perception of steady state when it has not yet

307 been achieved (Fig. 1). For example, aspartic acid was similar in $\delta^{13} \mathrm{C}$ values between diets: -

$30823 \%$ o for squid and $-26 \%$ for tilapia. Thus, after the switch from squid to tilapia, the aspartic acid

309 of the experimental shark muscle only needed to decline by $3 \%$ o to reach a new steady state, a

310 relatively small difference considering our analytical precision $(0.2-0.8 \%)$. By the end of the

311 experiment, aspartic acid appeared to have reached a steady state because its discrimination

312 factor in experimental sharks was nearly identical to that in control sharks. In contrast, the diets

313 had very different glycine $\delta^{13} \mathrm{C}$ values (-6\% for squid and $-16 \%$ or tilapia), and thus this amino

314 acid had to decline by $10 \%$ in shark muscle to reach a new steady state. As a result, by the end 
315 of the experiment, it was apparent that glycine had not yet reached the new steady state because

316 its discrimination factor for experimental individuals was still much larger than that of control

317 individuals (by $\sim 5 \%$ ).

318 The variable magnitude of the required shift in isotopic values after the diet switch can

319 also contribute to dissociation between carbon and nitrogen dynamics. For example, the carbon

320 in the glycine of muscle in the experimental sharks appeared to have not yet reached a steady

321 state because of the large change required in $\delta^{13} \mathrm{C}$ after the diet switch (10\%). However, the

322 required shift in glycine $\delta^{15} \mathrm{~N}$ was much smaller (1\%o). Thus, as would be expected, the glycine

$323 \Delta \Delta^{15} \mathrm{~N}$ value for experimental individuals appeared to be very similar to that of control

324 individuals, giving the appearance that the nitrogen in glycine was close to a steady state with the 325 new (tilapia) diet.

The apparent lack of a steady state for multiple amino acids must be reconciled with the

327 conclusion of Kim et al. (2012b) that the bulk muscle tissue of these same experimental sharks

328 had reached a steady state with their new diet for both carbon and nitrogen. We offer two

329 possible explanations for this discrepancy. First, the ostensibly steady isotope values of the bulk

330 tissue at the end of the experiment may have represented a temporary plateau in isotopic turnover

331 rather than a steady state. Incorporation of dietary isotopes usually does not occur at a uniform

332 rate, but instead depends upon protein turnover and tissue accretion (Carleton and Martínez del

333 Rio 2010). Body length measurements indicate that experimental sharks underwent annual

334 periods of accelerated growth during July-November, coinciding with seasonal increases in the 335 temperature of Monterey Bay seawater, which circulated in the shark tanks (Fig. S1 includes 336 serial measurements of body length and bulk muscle tissue $\delta^{13} \mathrm{C}$ and $\delta^{15} \mathrm{~N}$ for each shark, and 337 seawater temperature during the experiment). Warmer water temperatures likely increased both 
338

339

340

341

342

343

344

345

346

347

348

349

350

351

352

353

354

355

356

357

358

359

360

protein turnover and tissue accretion in the sharks (Pauly 1980; Fauconneau and Arnal 1985),

providing a mechanism for simultaneous rapid changes in tissue $\delta^{13} \mathrm{C}$ and $\delta^{15} \mathrm{~N}$ values. Kim et al. (2012b) collected their last serial sample during April, several months into a period of cooler water temperatures and relative stasis for both growth and changes in muscle tissue $\delta^{13} \mathrm{C}$ and $\delta^{15} \mathrm{~N}$ values. It is possible that had the study continued serial sampling through the following July-November, warmer water temperatures would have caused further change in bulk muscle $\delta^{13} \mathrm{C}$ and $\delta^{15} \mathrm{~N}$ values of the experimental sharks, removing the appearance of a final asymptote. In such a scenario, bulk isotope data would have indicated that sharks had not yet reached a steady state, consistent with the results that we report here for individual amino acids.

A second explanation is that the amino acid composition of shark muscle led to a bulk tissue isotopic value in experimental individuals, which obscured the lack of a steady state. Previous studies of other shark species (dogfish, Squalus acanthias; mako, Isurus oxyrinchus; sharphead, Scoliodon sorrakowah) indicate that their muscle contains amino acids that we did not measure (tryptophan, proline, hydroxyproline, methionine, cysteine, arginine, histidine, taurine; Chandrashekar and Deosthale 1993; Onodenalore and Shahidi 1996; Diniz and Martin 1997). We assumed that muscle of leopard sharks has similar amino acid composition as these other species. After accounting for the number of carbon and nitrogen atoms in the amino acids which we did not measure, they represent $20-22 \%$ of the total carbon and $28-31 \%$ of the total nitrogen in the protein of bulk muscle tissue. Thus, the amino acids we measured represent $\sim 80 \%$ of the total carbon and $\sim 70 \%$ of the total nitrogen in muscle. The amino acids that did not differ in $\Delta^{13} \mathrm{C}$ values between control and experimental sharks had likely reached a steady state in both groups. After accounting for their carbon and nitrogen atoms, these amino acids represent $52 \%$ of the total carbon in muscle, while the amino acids that were potentially not in steady state 
361 represent $28 \%$. Thus, at least half of the carbon in the bulk muscle tissue would have given the

362 appearance of a steady state. However, this is a less probable explanation for nitrogen. The

363 amino acids likely in steady state in the experimental sharks provide only $24 \%$ of the total

364 nitrogen in muscle, while those not in a steady state provide $46 \%$. Thus, nitrogen in the bulk

365 muscle tissue should have been more likely to represent incomplete isotopic turnover.

366 Overall, the magnitude of difference in $\delta^{13} \mathrm{C}$ or $\delta^{15} \mathrm{~N}$ values of amino acids between the

367 control (squid) and experimental (tilapia) diets appeared to be the most important influence on

368 differences in amino acid discrimination factors between groups in our study. This dynamic can

369 affect the ability to distinguish between steady state and incomplete turnover, especially for bulk

370 tissue analyses, because they represent the weighted average of isotopic values of all compounds

371 present in a tissue. This finding has important implications for the use of isotopic analysis in

372 captive feeding studies and for inferring diet of free-ranging individuals. To date, only two

373 studies have estimated isotopic incorporation rates of amino acids in marine organisms after a

374 diet switch: Bradley et al. (2014) reported on Pacific bluefin tuna (Thunnus orientalis) and

375 Downs et al. (2014) on Pacific white shrimp (Litopenaeus vannamei). The time required to

376 replace $95 \%$ of endogenous nitrogen varied among amino acids from 214-1836 days in tuna and

377 from 29-411 days in shrimp. Some of this variation may have been caused by $\delta^{15} \mathrm{~N}$ differences

378 among amino acids in the original diets prior to the start of the experiments. An amino acid with

379 a $\delta^{15} \mathrm{~N}$ value that was similar between old and new diets could appear to have a quicker isotopic

380 incorporation rate than an amino acid that differed substantially in $\delta^{15} \mathrm{~N}$ value between diets,

381 even if the turnover rates were identical (e.g., Fig. 1). Lastly, our conclusion that some amino

382 acids in experimental sharks had not reached steady state 685 days after a diet switch implies that

383 this tissue integrates diet information across multiple years. As a result, researchers should 
384 consider that isotopic composition of muscle in sharks and other large, ectothermic marine

385 consumers likely cannot reveal seasonal shifts in diet or habitat use.

387 Control sharks. We believe that discrimination factors for individual amino acids in control 388 sharks were accurate and not influenced by incomplete incorporation of the diet, for several 389 reasons. First, by the time of sampling at the end of the experiment, control individuals had been 390 on a constant diet for 1250 days and had not exhibited substantial, directional change in bulk

391 tissue $\delta^{13} \mathrm{C}$ or $\delta^{15} \mathrm{~N}$ values for $>400$ days (Kim et al. 2012a). Second, a recent review found that 392 the longest time interval reported for elasmobranch muscle to replace $95 \%$ of endogenous carbon 393 or nitrogen was 422 days (Galván et al. 2016). Although we propose that the appearance of 394 steady states may not always be reliable (as described in the previous section), the fact that 395 control sharks consumed the same diet for a period three times longer than the maximum 396 reported interval for $95 \%$ turnover makes it likely that they had reached a steady state. Data from control sharks supported our prediction that discrimination factors would be

398 larger than zero for non-essential amino acids. The largest $\Delta^{13} \mathrm{C}$ values in control sharks were for 399 aspartic acid and glutamic acid, suggesting extensive de novo synthesis. This result is consistent 400 with the roles of aspartic acid and glutamic acid as important metabolic intermediates in the 401 processing of nitrogen derived from amino acid catabolism, which is prevalent in 402 hypercarnivores such as the sharks in this study. In addition, aspartic acid and glutamic acid are 403 ketogenic and thus their synthetic pathways most immediately use other amino acids as a carbon 404 source, which would be plentiful for animals consuming a protein-rich diet. In contrast, control 405 sharks exhibited smaller $\Delta^{13} \mathrm{C}$ values for the glycolytic amino acids (glycine, serine, alanine), 406 which are primarily synthesized using carbohydrates as a carbon source, which were relatively 
407 limited in both diets. Glycine and alanine had positive $\Delta^{13} \mathrm{C}$ values, suggesting some de novo

408 synthesis, while serine was the only non-essential amino acid that did not support our

409 predictions. Serine had a $\Delta{ }^{13} \mathrm{C}$ value that did not differ from zero, suggesting that a substantial

410 portion of this amino acid in control sharks was routed directly from the diet into muscle.

411 Among the essential amino acids in muscle of control sharks, threonine, phenylalanine,

412 and lysine supported our prediction that their discrimination factors would not differ from zero.

413 This result indicates that sharks tended to directly route these amino acids into their muscle.

414 Surprisingly, the discrimination factors for isoleucine, leucine, and valine differed from zero. At

415 least two non-exclusive mechanisms could cause this pattern. First, dietary isoleucine, leucine,

416 and valine tend to be oxidized for energy at a higher rate than dietary threonine, phenylalanine,

417 and lysine (Wu 1998). If the degradative enzymes (i.e., the branched-chain alpha-keto acid

418 dehydrogenase complex) preferably catabolize dietary isoleucine, leucine, and valine with ${ }^{12} \mathrm{C}$

419 atoms, the $\delta^{13} \mathrm{C}$ value of the remaining, assimilated amino acids would increase and the $\Delta^{13} \mathrm{C}$

420 values would be positive. Second, isoleucine, leucine, and valine are all synthesized by the same

421 biochemical pathway from pyruvate, which is absent in animals. Because sharks in this study

422 were exclusively fed a known diet, positive $\Delta^{13} \mathrm{C}$ values could reflect contribution from

423 symbiotic microbes (Givens et al. 2015). For instance, gut microbes have been shown to play an

424 important role in digestion for bonnethead sharks (Sphyrna tiburo; Jhaveri et al. 2015). Although

425 it is counterintuitive that an animal consuming a high-protein diet would rely on microbes for

426 essential amino acids that are incorporated into tissue, this could be related to a role for such

427 microbes in the recycling of urea, as discussed below. Future research should investigate the

428 potential flux of amino acids from microbes to shark hosts, since this process could confound

429 identification of primary producers in a food web based on $\delta^{13} \mathrm{C}$ values of consumer tissue. 
431 that our $\Delta^{15} \mathrm{~N}$ results are similar to those of Hoen et al. (2014), who analyzed the same control

432 sharks in a larger study of carnivorous fish; Fig. S2). Trophic amino acids exhibited a mean $\Delta^{15} \mathrm{~N}$

433 value of $3.8 \%$ o $( \pm 1.4 \mathrm{SD})$, supporting our prediction that these discrimination factors would be

434 larger than zero. Notably, this value is lower than the average $\Delta^{15} \mathrm{~N}$ of $5.4 \%$ from a recent meta-

435 analysis of published trophic amino acid discrimination factors in studies of consumers with

436 controlled or well-constrained dietary sources (McMahon and McCarthy 2016). However, our

$437 \Delta^{15} \mathrm{~N}$ values were similar to those reported from controlled feeding experiments with other

438 sharks and a carnivorous fish (opakapaka; Pristipomoides filamentosus; Hoen et al. 2014). Lower

439 than expected $\Delta^{15} \mathrm{~N}$ values of trophic amino acids have also been predicted for free-ranging

440 brown stingrays (Dasyatic lata) and scalloped hammerhead sharks (Sphyrna lewini) to reconcile

441 unrealistically low trophic positions based on a compound-specific approach with higher trophic

442 positions based on stomach content and bulk tissue isotope analysis (Dale et al. 2011). Such low

443 values of $\Delta^{15} \mathrm{~N}$ could be caused by a high protein diet, which has been associated with reduced

444 isotopic discrimination in both bulk tissue (Hughes et al. 2018) and individual amino acids

445 (McMahon et al. 2015), potentially because of a reduced need for de novo protein synthesis.

446 However, for some amino acids in our study, this explanation conflicts with the simultaneous

447 inference that elevated $\Delta^{13} \mathrm{C}$ values are indicative of extensive de novo synthesis. For example,

448 among non-essentials, aspartic acid and glutamic acid exhibited $\Delta^{13} \mathrm{C}$ values of $9-16 \%$ but $\Delta^{15} \mathrm{~N}$

449 values of only $2-4 \%$.

450 We suggest that the relatively small $\Delta^{15} \mathrm{~N}$ values of trophic amino acids in the control

451 sharks were not necessarily caused by reduced rates of amino acid synthesis, but instead by

452 recycling of urea nitrogen (Germain et al. 2013; McMahon and McCarthy 2016). In ureotelic 
453 animals, catabolism of amino acids creates a pool of nitrogen, of which ${ }^{14} \mathrm{~N}$ is selectively

454 incorporated into urea then excreted. The remaining nitrogen pool becomes relatively enriched in

$455{ }^{15} \mathrm{~N}$ and is used for synthesis of some endogenous amino acids, leading to large $\Delta^{15} \mathrm{~N}$ values (Lee 456 et al. 2012). However, sharks retain urea for use as a tissue osmolyte (Ballantyne 1997). This

457 process is so important that some sharks synthesize additional urea by converting ammonia from 458 surrounding seawater (Wood and Giacomin 2016). Sharks, like most vertebrates, likely lack the 459 enzymes for hydrolyzing urea and recycling its nitrogen but can host populations of bacteria 460 capable of urea hydrolysis (Stevens and Hume 1998). Indeed, such populations occur in shark 461 muscle (Grimes et al. 1985) and bacterially-mediated urea breakdown has been demonstrated in 462 shark liver tissue (Knight et al. 1988). Sharks have high rates of amino acid catabolism and urea 463 production, which would typically lead to elevated $\Delta^{15} \mathrm{~N}$ values if that urea was excreted; but 464 they retain it and it is highly feasible that sharks then rely on bacterial symbionts to break down 465 the urea and make the nitrogen therein available for re-use. The incorporation of ${ }^{14} \mathrm{~N}$ recycled 466 from urea into newly-synthesized amino acids and endogenous tissue could explain the low $\Delta^{15} \mathrm{~N}$ 467 values of trophic amino acids in sharks. This assimilation of microbially-produced amino acids 468 could also lead to the non-zero $\Delta^{13} \mathrm{C}$ that we observed for some essential amino acids.

469 Researchers interpreting isotope data from free-ranging elasmobranchs should consider that 470 individuals may recycle urea and exhibit a $\Delta^{15} \mathrm{~N}$ lower than expected for an upper trophic level 471 consumer (McMahon and McCarthy 2016). Unless this potential bias is accounted for, trophic 472 position may be substantially underestimated (Dale et al. 2011; Nielsen et al. 2015).

473 Among source amino acids in control sharks, we found a continuum of $\Delta^{15} \mathrm{~N}$ values, 474 similar to previous studies (McMahon and McCarthy 2016). Only the discrimination factor for 475 phenylalanine met our expectation of not differing from zero, emphasizing its role as a true 
476 source amino acid that tracks the $\delta^{15} \mathrm{~N}$ value of producers at the base of the food web. The other

477 source amino acids (lysine, tyrosine) had discrimination factors that differed from zero and

478 overlapped with at least one trophic amino acid. Glycine also had a positive discrimination

479 factor, and for control sharks serine exhibited a surprisingly negative discrimination factor; this 480 reinforces the recent conclusion that these two amino acids should not be classified as "source"

481 because of their highly-variable discrimination factors in different systems (McMahon and

482 McCarthy 2016). In combination, the patterns in our data suggest that studies of elasmobranchs

483 should consider phenylalanine as the most reliable source amino acid, although this conclusion

484 should be tested in other elasmobranch species.

485

486 Conclusion. Elasmobranchs have important ecological roles and can structure marine

487 communities (Young et al. 2015; Bird et al. 2018). Stable isotope analysis can be a powerful tool

488 for assessing these roles (Hussey et al. 2011; Shiffman et al. 2012) but an understanding of how

489 the unique physiology of elasmobranchs influences tissue isotopic patterns is needed to better

490 interpret data collected from wild populations. Overall, we observed higher than expected $\Delta^{13} \mathrm{C}$

491 values for essential amino acids (possibly because of microbial contributions), lower than

492 expected $\Delta^{15} \mathrm{~N}$ values for trophic amino acids (likely because of urea recycling), and evidence

493 that turnover in muscle is slow enough such that shark diet likely cannot be resolved at sub-

494 annual time scales, an issue that can be exacerbated by switching among diet items which differ

495 substantially in $\delta^{13} \mathrm{C}$ or $\delta^{15} \mathrm{~N}$ values. Future studies of free-ranging elasmobranchs should

496 account for these influences when inferring diet composition, trophic level, and habitat use.

497 When these questions are addressed with amino acid isotope data, researchers can include

498 sensitivity analyses of how their conclusions vary after adjusting discrimination factors based on 
499 our results. This will help illustrate the capabilities and limitations of isotope-based approaches

500 in ecology.

501

502 Acknowledgements

503 We thank the Institute of Marine Sciences and Long Marine Lab at UC Santa Cruz for help in 504 acquiring and housing sharks; D. Casper for consultation and training throughout the experiment; 505 and volunteers (J. Adams, A. Bennett, M. Gorey, L. Krol, S. Perry, S. Rumbolt, A. Sjostrom, A. 506 Thell and C. Spencer) for assistance with husbandry and sampling. Thank you to L. Germain, F. 507 Batista, and M. McCarthy for preliminary CSIA results and encouragement to pursue this 508 project. Funds for experimental infrastructure were from a National Science Foundation award to 509 P. Koch (OCE 0345943) and from research funding provided to S. Kim (University of 510 Kentucky). All applicable institutional and/or national guidelines for the care and use of animals 511 were followed. 


\section{References}

513

514

515

516

517

518

519

520

521

522

523

524

525

526

527

528

529

530

531

532

533

534

535

536

537

538

539

540

541

542

543

544

545

546

Ballantyne JS (1997) Jaws: the inside story. The metabolism of elasmobranch fishes. Comp Biochem Physiol B Biochem Mol Biol 118:703-742. doi: 10.1016/S03050491(97)00272-1

Bird CS, Veríssimo A, Magozzi S, et al (2018) A global perspective on the trophic geography of sharks. Nat Ecol Evol 2:299-305. doi: 10.1038/s41559-017-0432-Z

Bradley CJ, Madigan DJ, Block BA, Popp BN (2014) Amino acid isotope incorporation and enrichment factors in Pacific Bluefin Tuna, Thunnus orientalis. PLOS ONE 9:e85818. doi: 10.1371/journal.pone.0085818

Cantalapiedra-Hijar G, Dewhurst RJ, Cheng L, et al (2017) Nitrogen isotopic fractionation as a biomarker for nitrogen use efficiency in ruminants: a meta-analysis. Animal 1-11. doi: $10.1017 / \mathrm{S} 1751731117003391$

Carleton SA, Martínez del Rio C (2010) Growth and catabolism in isotopic incorporation: a new formulation and experimental data. Funct Ecol 24:805-812

Chandrashekar K, Deosthale YG (1993) Proximate composition, amino acid, mineral, and trace element content of the edible muscle of 20 Indian fish species. J Food Compos Anal $6: 195-200$

Chikaraishi Y, Kashiyama Y, Ogawa NO, et al (2007) Metabolic control of nitrogen isotope composition of amino acids in macroalgae and gastropods: implications for aquatic food web studies. Mar Ecol Prog Ser 342:85-90. doi: 10.3354/meps342085

Dale J, Wallsgrove N, Popp B, Holland K (2011) Nursery habitat use and foraging ecology of the brown stingray Dasyatis lata determined from stomach contents, bulk and amino acid stable isotopes. Mar Ecol Prog Ser 433:221-236. doi: 10.3354/meps09171

Diniz FM, Martin AM (1997) Optimization of nitrogen recovery in the enzymatic hydrolysis of dogfish (Squalus acanthias) protein. Composition of the hydrolysates. Int J Food Sci Nutr 48:191-200. doi: 10.3109/09637489709012592

Downs E, Popp B, Holl C (2014) Nitrogen isotope fractionation and amino acid turnover rates in the Pacific white shrimp Litopenaeus vannamei. Mar Ecol Prog Ser 516:239-250. doi: $10.3354 /$ meps 11030

Engel MH, Hare PE (1985) Gas-liquid chromatographic separation of amino acids and their derivatives. In: Barrett GC (ed) Chemistry and Biochemistry of the Amino Acids.

Springer Netherlands, pp 462-479

Fantle MS, Dittel AI, Schwalm SM, et al (1999) A food web analysis of the juvenile blue crab, Callinectes sapidus, using stable isotopes in whole animals and individual amino acids. Oecologia 120:416-426. doi: 10.1007/s004420050874 
Fauconneau B, Arnal M (1985) In vivo protein synthesis in different tissues and the whole body of rainbow trout (Salmo gairdnerii R.). Influence of environmental temperature. Comp Biochem Physiol A 82:179-187. doi: 10.1016/0300-9629(85)90723-6

Florin ST, Felicetti LA, Robbins CT (2011) The biological basis for understanding and predicting dietary-induced variation in nitrogen and sulphur isotope ratio discrimination. Funct Ecol 25:519-526

Galván DE, Jañez J, Irigoyen AJ (2016) Estimating tissue-specific discrimination factors and turnover rates of stable isotopes of nitrogen and carbon in the smallnose fanskate Sympterygia bonapartii (Rajidae): estimating tdf values in s. bonapartii. J Fish Biol 89:1258-1270. doi: 10.1111/jfb.13024

Germain LR, Koch PL, Harvey J, McCarthy MD (2013) Nitrogen isotope fractionation in amino acids from harbor seals: implications for compound-specific trophic position calculations. Mar Ecol Prog Ser 482:265-277. doi: 10.3354/meps 10257

Givens C, Ransom B, Bano N, Hollibaugh J (2015) Comparison of the gut microbiomes of 12 bony fish and 3 shark species. Mar Ecol Prog Ser 518:209-223. doi: 10.3354/meps11034

Grimes DJ, Brayton P, Colwell RR, Gruber SH (1985) Vibrios as autochthonous flora of neritic sharks. Syst Appl Microbiol 6:221-226. doi: 10.1016/S0723-2020(85)80056-4

Hoen DK, Kim SL, Hussey NE, et al (2014) Amino acid ${ }^{15} \mathrm{~N}$ trophic enrichment factors of four large carnivorous fishes. J Exp Mar Biol Ecol 453:76-83. doi: 10.1016/j.jembe.2014.01.006

Howland MR, Corr LT, Young SMM, et al (2003) Expression of the dietary isotope signal in the compound-specific $\delta^{13} \mathrm{C}$ values of pig bone lipids and amino acids. Int J Osteoarchaeol 13:54-65. doi: 10.1002/oa.658

Hughes KL, Whiteman JP, Newsome SD (2018) The relationship between dietary protein content, body condition, and $\Delta^{15} \mathrm{~N}$ in a mammalian omnivore. Oecologia 186:357-367. doi: $10.1007 / \mathrm{s} 00442-017-4010-5$

Hussey NE, Brush J, McCarthy ID, Fisk AT (2010) $\delta^{15} \mathrm{~N}$ and $\delta^{13} \mathrm{C}$ diet-tissue discrimination factors for large sharks under semi-controlled conditions. Comp Biochem Physiol A Mol Integr Physiol 155:445-453. doi: 10.1016/j.cbpa.2009.09.023

Hussey NE, Dudley SFJ, McCarthy ID, et al (2011) Stable isotope profiles of large marine predators: viable indicators of trophic position, diet, and movement in sharks? Can J Fish Aquat Sci 68:2029-2045. doi: 10.1139/f2011-115

Jhaveri P, Papastamatiou YP, German DP (2015) Digestive enzyme activities in the guts of bonnethead sharks (Sphyrna tiburo) provide insight into their digestive strategy and evidence for microbial digestion in their hindguts. Comp Biochem Physiol A Mol Integr Physiol 189:76-83. doi: 10.1016/j.cbpa.2015.07.013 
Jim S, Jones V, Ambrose SH, Evershed RP (2006) Quantifying dietary macronutrient sources of carbon for bone collagen biosynthesis using natural abundance stable carbon isotope analysis. Br J Nutr 95:1055-1062. doi: 10.1079/BJN20051685

Kelly LJ, Martínez del Rio C (2010) The fate of carbon in growing fish: an experimental study of isotopic routing. Physiol Biochem Zool 83:473-480

Kim SL, Casper DR, Galván-Magaña F, et al (2012a) Carbon and nitrogen discrimination factors for elasmobranch soft tissues based on a long-term controlled feeding study. Environ Biol Fishes 95:37-52. doi: 10.1007/s10641-011-9919-7

Kim SL, Koch PL (2012) Methods to collect, preserve, and prepare elasmobranch tissues for stable isotope analysis. Environ Biol Fishes 95:53-63. doi: 10.1007/s10641-011-9860-9

Kim SL, Martínez del Rio C, Casper D, Koch PL (2012b) Isotopic incorporation rates for shark tissues from a long-term captive feeding study. J Exp Biol 215:2495-2500. doi: 10.1242/jeb.070656

Knight IT, Grimes DJ, Colwell RR (1988) Bacterial hydrolysis of urea in the tissues of carcharhinid sharks. Can J Fish Aquat Sci 45:357-360

Lee TN, Buck CL, Barnes BM, O’Brien DM (2012) A test of alternative models for increased tissue nitrogen isotope ratios during fasting in hibernating arctic ground squirrels. J Exp Biol 215:3354-3361. doi: 10.1242/jeb.068528

Lorrain A, Graham BS, Popp BN, et al (2015) Nitrogen isotopic baselines and implications for estimating foraging habitat and trophic position of yellowfin tuna in the Indian and Pacific Oceans. Deep Sea Res Part II Top Stud Oceanogr 113:188-198. doi: 10.1016/j.dsr2.2014.02.003

Malpica-Cruz L, Herzka SZ, Sosa-Nishizaki O, et al (2012) Tissue-specific isotope trophic discrimination factors and turnover rates in a marine elasmobranch: empirical and modeling results. Can J Fish Aquat Sci 69:551-564. doi: 10.1139/f2011-172

Martínez del Rio C, Carleton SA (2012) How fast and how faithful: the dynamics of isotopic incorporation into animal tissues. J Mammal 93:353-359

Martínez del Rio CM, Wolf N, Carleton SA, Gannes LZ (2009) Isotopic ecology ten years after a call for more laboratory experiments. Biol Rev 84:91-111

McMahon KW, Fogel ML, Elsdon TS, Thorrold SR (2010) Carbon isotope fractionation of amino acids in fish muscle reflects biosynthesis and isotopic routing from dietary protein. J Anim Ecol 79:1132-1141. doi: 10.1111/j.1365-2656.2010.01722.x

McMahon KW, McCarthy MD (2016) Embracing variability in amino acid $\delta^{15} \mathrm{~N}$ fractionation: mechanisms, implications, and applications for trophic ecology. Ecosphere 7:e01511. doi: $10.1002 /$ ecs 2.1511 
McMahon KW, Thorrold SR, Elsdon TS, McCarthy MD (2015) Trophic discrimination of nitrogen stable isotopes in amino acids varies with diet quality in a marine fish: Trophic discrimination of amino acids. Limnol Oceanogr 60:1076-1087. doi: 10.1002/lno.10081

Newsome SD, Fogel ML, Kelly L, Martínez del Rio C (2011) Contributions of direct incorporation from diet and microbial amino acids to protein synthesis in Nile tilapia. Funct Ecol 25:1051-1062. doi: 10.1111/j.1365-2435.2011.01866.x

Newsome SD, Wolf N, Peters J, Fogel ML (2014) Amino acid $\delta^{13} \mathrm{C}$ analysis shows flexibility in the routing of dietary protein and lipids to the tissue of an omnivore. Integr Comp Biol 54:890-902. doi: 10.1093/icb/icu106

Nielsen JM, Popp BN, Winder M (2015) Meta-analysis of amino acid stable nitrogen isotope ratios for estimating trophic position in marine organisms. Oecologia 178:631-642. doi: $10.1007 / \mathrm{s} 00442-015-3305-7$

O'Connell TC (2017) 'Trophic' and 'source' amino acids in trophic estimation: a likely metabolic explanation. Oecologia 184:317-326. doi: 10.1007/s00442-017-3881-9

Onodenalore AC, Shahidi F (1996) Protein dispersions and hydrolysates from sharks (Isurus oxyrinchus). J Aquat Food Prod Technol 5:43-59

Pauly D (1980) On the interrelationships between natural mortality, growth parameters, and mean environmental temperature in 175 fish stocks. ICES J Mar Sci 39:175-192. doi: 10.1093/icesjms/39.2.175

Post DM, Layman CA, Arrington DA, et al (2007) Getting to the fat of the matter: models, methods and assumptions for dealing with lipids in stable isotope analyses. Oecologia 152:179-189

Robbins CT, Felicetti LA, Sponheimer M (2005) The effect of dietary protein quality on nitrogen isotope discrimination in mammals and birds. Oecologia 144:534-540

Shiffman DS, Gallagher AJ, Boyle MD, et al (2012) Stable isotope analysis as a tool for elasmobranch conservation research: a primer for non-specialists. Mar Freshw Res 63:635. doi: 10.1071/MF11235

Stevens CE, Hume ID (1998) Contributions of microbes in vertebrate gastrointestinal tract to production and conservation of nutrients. Physiol Rev 78:393-427

USDA National Nutrient Database for Standard Reference Legacy Release. https://ndb.nal.usda.gov/ndb/foods/show/303613?fgcd=\&manu=\&lfacet=\&format=\&cou $\mathrm{nt}=\& \max =25 \&$ offset $=\&$ sort $=$ default\&order $=$ asc \&qlookup $=$ tilapia\&ds $=\& \mathrm{qt}=\& \mathrm{qp}=\& \mathrm{qa}=$ $\& \mathrm{qn}=\& \mathrm{q}=\&$ ing $=$. Accessed 18 Apr 2018

Vander Zanden MJ, Clayton MK, Moody EK, et al (2015) Stable isotope turnover and half-life in animal tissues: a literature synthesis. PLoS ONE 10:e0116182. doi: 10.1371/journal.pone.0116182 
654 Vokhshoori NL, McCarthy MD (2014) Compound-specific $\delta^{15} \mathrm{~N}$ amino acid measurements in 655 littoral mussels in the California Upwelling ecosystem: A new approach to generating baseline $\delta^{15} \mathrm{~N}$ isoscapes for coastal ecosystems. PLOS ONE 9:e98087. doi:

658 Wood CM, Giacomin M (2016) Feeding through your gills and turning a toxicant into a resource: how the dogfish shark scavenges ammonia from its environment. J Exp Biol 219:3218-3226. doi: 10.1242/jeb.145268

661 Wu G (1998) Intestinal mucosal amino acid catabolism. J Nutr 128:4p

662 Young JW, Hunt BPV, Cook TR, et al (2015) The trophodynamics of marine top predators:

663 Current knowledge, recent advances and challenges. Deep Sea Res Part II Top Stud

664 Oceanogr 113:170-187. doi: 10.1016/j.dsr2.2014.05.015

665 Zeichner SS, Colman AS, Koch PL, et al (2017) Discrimination factors and incorporation rates 666 for organic matrix in shark teeth based on a captive feeding study. Physiol Biochem Zool 667 90:257-272. doi: 10.1086/689192 
668 Table 1. Amino acid composition (mole percent) of the muscle of leopard sharks $(\mathrm{N}=3)$ and two

669 prey items, squid $(\mathrm{N}=1)$ and tilapia $(\mathrm{N}=1)$. Amino acids are classified for carbon as essential

670 (E) or non-essential $(\mathrm{N})$, and for nitrogen as source $(\mathrm{S})$ or trophic $(\mathrm{T})$. For nitrogen, threonine is

671 considered neither source nor trophic, and serine and glycine can act as either source or trophic

672 depending upon the organism and ecosystem. Shark data are reproduced from Kim and Koch

673 (2012).

674

\begin{tabular}{|c|c|c|c|c|}
\hline Classification & Amino Acid & Shark & Squid & Tilapia \\
\hline$\overline{\mathbf{E}}$ & Threonine & 6.0 & 7.0 & 8.0 \\
\hline ES & Lysine & 11.1 & 7.9 & 5.1 \\
\hline ES & Phenylalanine & 4.0 & 4.2 & 4.5 \\
\hline ET & Isoleucine & 4.1 & 4.7 & 4.0 \\
\hline ET & Valine & 6.4 & 7.3 & 8.7 \\
\hline ET & Leucine & 9.3 & 10.1 & 9.3 \\
\hline NT & Aspartic Acid & 13.4 & 13.5 & 13.3 \\
\hline NT & Glutamic Acid & 10.2 & 9.5 & 7.8 \\
\hline NT & Alanine & 10.4 & 12.3 & 10.1 \\
\hline NT & Proline & 5.3 & 4.7 & 6.5 \\
\hline NS & Tyrosine & 1.7 & 1.6 & 2.7 \\
\hline NT/S & Serine & 6.2 & 7.0 & 10.2 \\
\hline NT/S & Glycine & 12.0 & 10.2 & 9.8 \\
\hline
\end{tabular}

675

676 
677 Table 2. Test statistics for linear regression models in which amino acid imbalance between

678 leopard sharks and their diet (measured as the difference in mole percent) was the predictor of

679 stable isotope discrimination factors $\left(\Delta^{13} \mathrm{C}\right.$ and $\left.\Delta^{15} \mathrm{~N}\right)$ between leopard sharks and their diet. Two

680 groups of sharks were evaluated: control (fed a constant diet of squid for 1250 days) and

681 experimental (diet switched to tilapia on day 565). One model exhibited a significant relationship

682 as indicated by an asterisk. However, after removal of a single data point (serine) on the basis of

683 a high Cook's Distance score, the relationship was not significant.

684

\begin{tabular}{|c|c|c|c|c|c|c|c|}
\hline Predictor & Response & Group & Amino acids & $\mathbf{N}$ & $P$ & $\mathbf{F}$ & $\mathbf{R}^{2}$ \\
\hline \multirow{9}{*}{$\begin{array}{c}\text { Amino } \\
\text { acid } \\
\text { imbalance }\end{array}$} & \multirow{2}{*}{$\Delta^{13} \mathrm{C}$} & Control & All & 12 & 0.95 & 0.00 & $<0.01$ \\
\hline & & Control & Non-essential & 6 & 0.66 & 0.22 & $<0.01$ \\
\hline & \multirow{2}{*}{$\Delta^{15} \mathrm{~N}$} & Control & All & 12 & 0.52 & 0.44 & $<0.01$ \\
\hline & & Control & Trophic & 6 & 0.93 & 0.01 & $<0.01$ \\
\hline & \multirow{3}{*}{$\Delta^{13} \mathrm{C}$} & Experimental & All & 12 & 0.62 & 0.25 & $<0.01$ \\
\hline & & Experimental & Non-essential* & 6 & 0.05 & 7.73 & 0.57 \\
\hline & & Experimental & $\begin{array}{l}\text { Non-essential } \\
\text { (no serine) }\end{array}$ & 5 & 0.41 & 0.93 & $<0.01$ \\
\hline & \multirow{2}{*}{$\Delta^{15} \mathrm{~N}$} & Experimental & All & 12 & 0.66 & 0.21 & $<0.01$ \\
\hline & & Experimental & Trophic & 6 & 0.96 & 0.00 & $<0.01$ \\
\hline
\end{tabular}

685 
687 Table 3. The percent of carbon and nitrogen estimated to have turned over in pools of individual 688 amino acids in the muscle of six leopard sharks after a 1250-day experiment. Sharks were fed 689 squid (days 0-565) then tilapia (days 566-1250).

690

\begin{tabular}{clc}
\hline Element & Amino acid & Turnover (\%) \\
\hline \multirow{4}{*}{$\mathrm{C}$} & Glycine & 50 \\
& Phenylalanine & 36 \\
& Lysine & 52 \\
& Isoleucine & 64 \\
\hline \multirow{4}{*}{$\mathrm{N}$} & Alanine & 34 \\
& Aspartic acid & 30 \\
& Glutamic acid & 29 \\
& Isoleucine & 31 \\
& Leucine & 32 \\
& Valine & 42 \\
& Serine & 17 \\
& Threonine & 47 \\
\hline
\end{tabular}

691 
692 Figure 1. Conceptual figure illustrating the effect of incomplete turnover on the appearance of

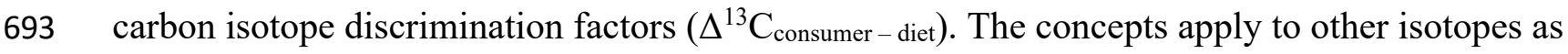

694 well. a-c) Each panel represents the $\delta^{13} \mathrm{C}$ values of an amino acid (X, Y, or Z) measured in the

695 tissue of a consumer (black line) that switched from an old diet to a new diet (dashed gray lines)

696 on day 0 . Each amino acid had the same turnover rate and if the consumer was in a steady state

697 with its diet a $\Delta^{13} \mathrm{C}$ value of $2 \%$. The y-axis is identical across panels. The differences in $\delta^{13} \mathrm{C}$

698 values between the old diet and new diet cause $\Delta^{13} \mathrm{C}$ to differ between days $100\left(\Delta_{100}\right)$ and 500

$699\left(\Delta_{500}\right)$. d) On day 100 , amino acid $\mathrm{X}$ already had a $\Delta^{13} \mathrm{C}$ value that was close to $2 \%$ because the

700 old diet and new diet were similar in $\delta^{13} \mathrm{C}$ values. However, for amino acid $\mathrm{Z}, \Delta^{13} \mathrm{C}$ was much

701 larger than $2 \%$ because the old diet and new diet differed substantially in $\delta^{13} \mathrm{C}$ values. e) On day

702500 , when turnover was nearly complete, each amino acid had a $\Delta^{13} \mathrm{C}$ value of about $2 \%$.

703

704 Figure 2. Carbon isotope values of individual amino acids in leopard shark muscle and in diet

705 items of the sharks. Box plots indicate median (solid line) and $25^{\text {th }}, 10^{\text {th }}$, and $5^{\text {th }}$ percentiles. a)

$706 \delta^{13} \mathrm{C}$ values of control sharks (fed squid for 1250 days; $\mathrm{N}=3$ ), experimental sharks (switched to

707 a diet of tilapia on day $565 ; \mathrm{N}=6$ ), and their respective diet items (squid, $\mathrm{N}=3$; tilapia, $\mathrm{N}=2$ ).

708 b) Discrimination factors $\left(\Delta^{13} \mathrm{C}\right)$ for control and experimental sharks. Asterisks above boxes

709 indicate $P$ values for a one-tailed t-test of whether discrimination factors differed from zero (test

710 statistics listed in Table S2). Brackets and asterisks below boxes indicate $P$ values for a two-

711 tailed t-test of whether control and experimental sharks differed (test statistics listed in Table

$712 \mathrm{~S} 3)$. 
714 Figure 3. Variation in consumer-diet isotope discrimination factors $(\Delta)$ for the a) carbon and b)

715 nitrogen of individual amino acids in muscle tissue of leopard sharks in a control group

716 (consumed squid for 1250 days) or experimental group (switched to tilapia on day 565). The x-

717 axes represent the difference between the mean isotopic value of each amino acid for control

718 (squid) diet and the experimental (tilapia) diet for a) $\delta^{13} \mathrm{C}$ and b) $\delta^{15} \mathrm{~N}$. The y-axes represent the

719 difference in the mean discrimination factor of each amino acid between experimental and

720 control individuals. The solid line represents a linear regression (dashed line is 95\% CI). Once an

721 animal reaches a steady state with a new diet the slope in each panel should be zero, if the new

722 diet has similar protein quality and content as the old diet.

723

724 Figure 4. Nitrogen isotope values of individual amino acids in leopard shark muscle and in diet 725 items of the sharks. Box plots indicate median (solid line) and $25^{\text {th }}, 10^{\text {th }}$, and $5^{\text {th }}$ percentiles. a) $726 \delta^{15} \mathrm{~N}$ of control sharks (fed squid for 1250 days; $\mathrm{N}=3$ ), experimental sharks (switched to a diet 727 of tilapia on day $565 ; \mathrm{N}=6$ ), and their respective diet items (squid, $\mathrm{N}=3$; tilapia, $\mathrm{N}=2$ ). Note 728 that the box for tyrosine in the experimental diet is difficult to see because it is small and nearly 729 identical to the line which forms the bottom of the box for experimental sharks (i.e., $10^{\text {th }}$ 730 percentile for the experimental sharks). b) Discrimination factors $\left(\Delta^{15} \mathrm{~N}\right)$ for control and 731 experimental sharks. Asterisks above boxes indicate $P$ values for a one-tailed t-test of whether 732 discrimination factors differed from zero (test statistics listed in Table S2). Brackets and asterisks 733 below boxes indicate $P$ values for a two-tailed t-test of whether control and experimental sharks 734 differed (test statistics listed in Table S3). 


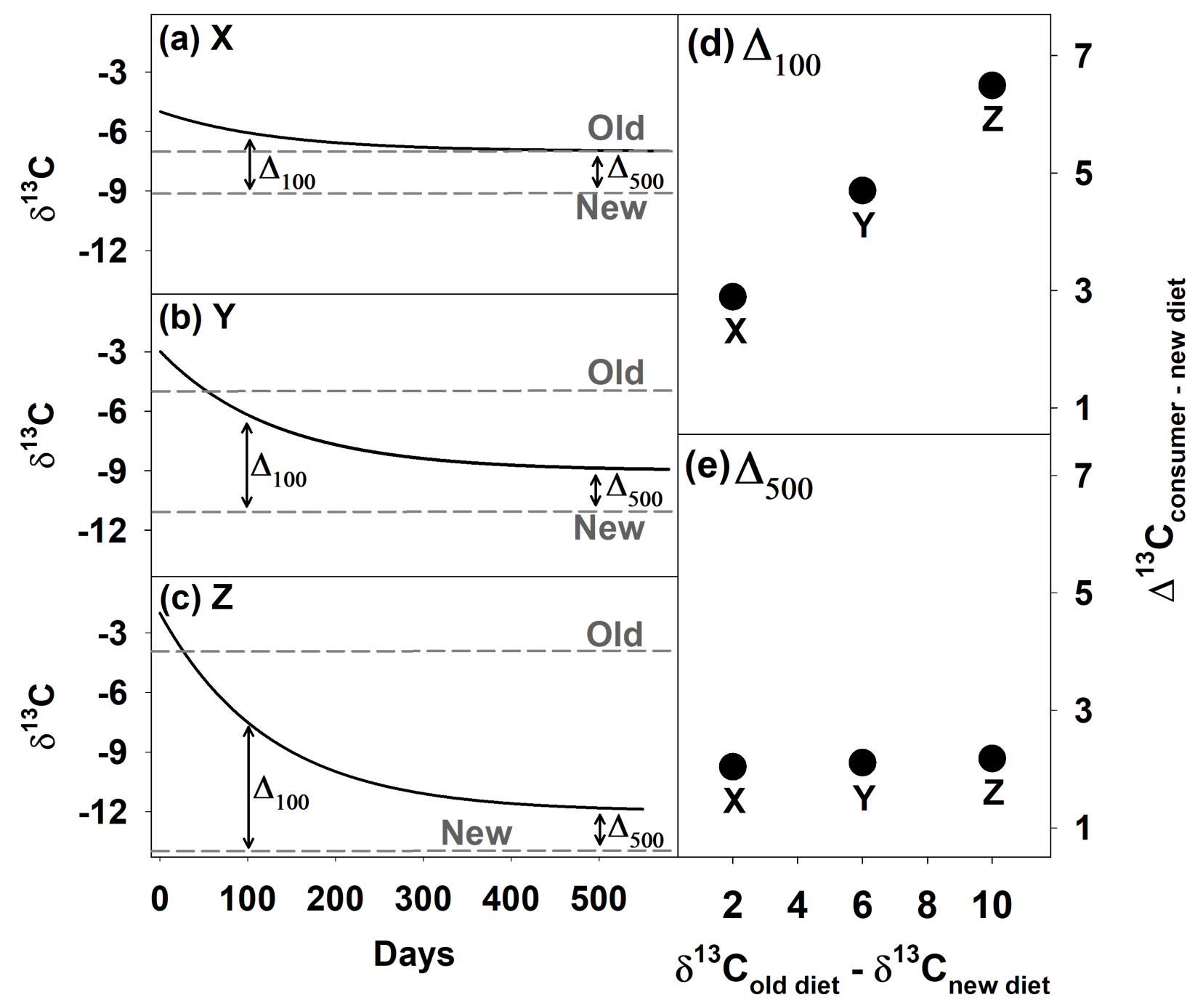

738 Figure 1.

739

740

741

742

743

744

745 

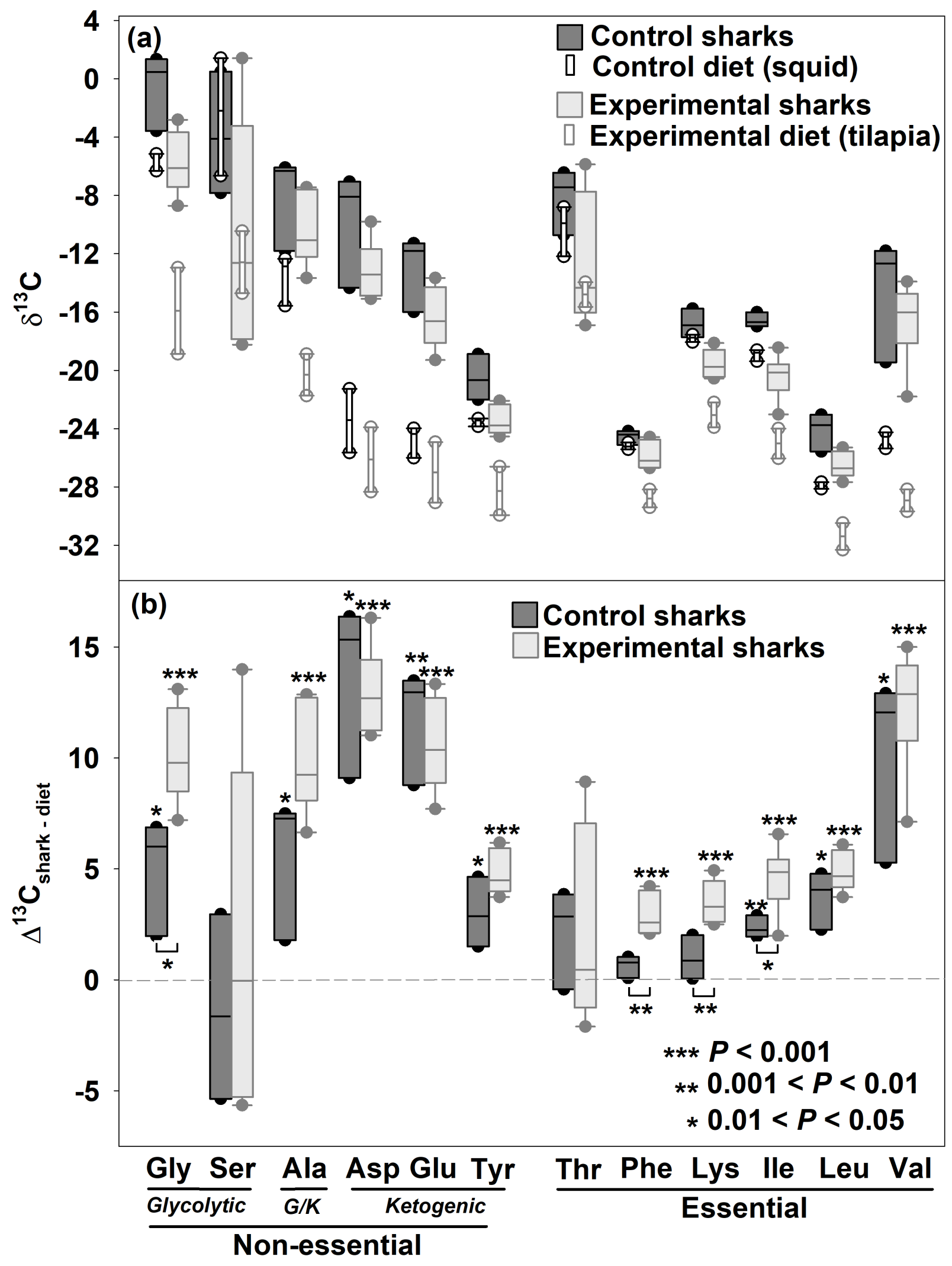

Figure 2. 

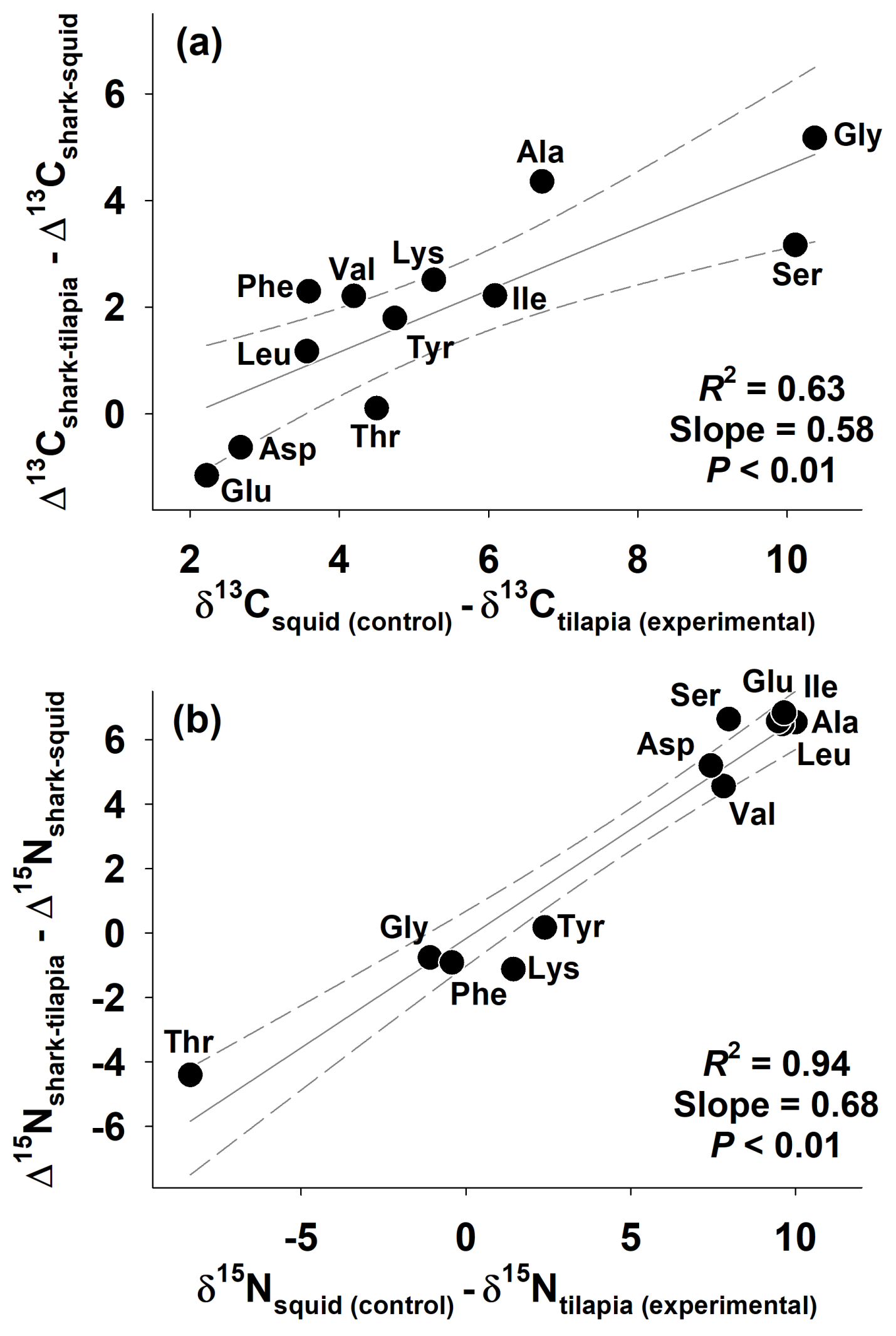

Figure 3. 


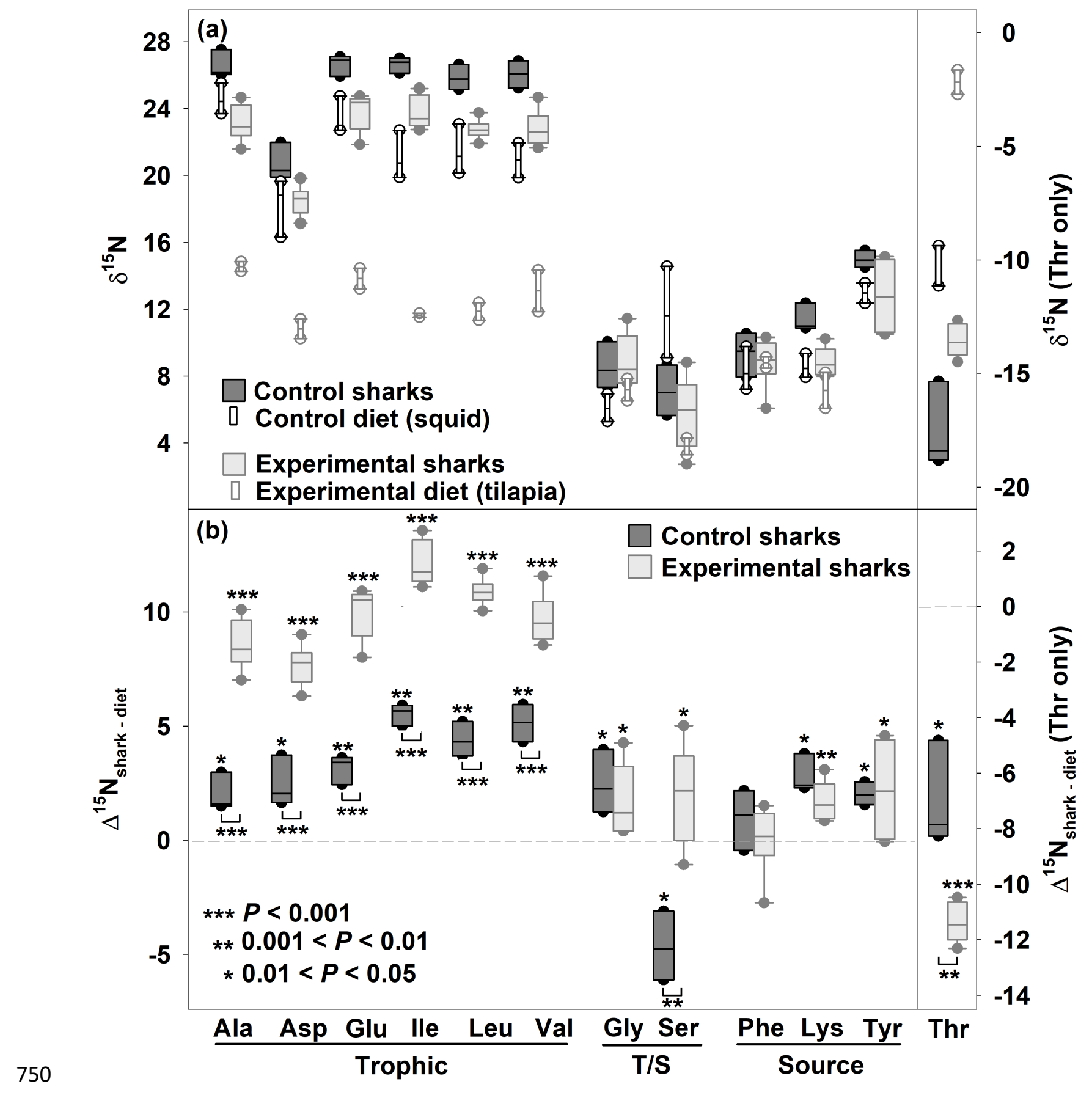

$751 \quad$ Figure 4. 
Amino acid isotope discrimination factors for a carnivore: physiological insights from leopard sharks and their diet

\title{
Supplementary Materials
}

\author{
Authors \\ John P. Whiteman ${ }^{1 *}$, Sora L. Kim²,3, Kelton W. McMahon ${ }^{4}$, Paul L. Koch ${ }^{2}$, Seth D. Newsome ${ }^{1}$ \\ Affiliations \\ ${ }^{1}$ Department of Biology, University of New Mexico, Albuquerque, New Mexico, 87131, USA \\ ${ }^{2}$ Department of Earth and Planetary Sciences, University of California, Santa Cruz, California, \\ 95064, USA \\ ${ }^{3}$ Current affiliation: Life and Environmental Sciences, University of California, Merced, \\ California, 95343, USA \\ ${ }^{4}$ Graduate School of Oceanography, University of Rhode Island, Narragansett, Rhode Island, \\ 02882, USA \\ *Corresponding author; jwhiteman@unm.edu; 307.760.1973
}


Table S1. Bulk carbon and nitrogen isotope measurements of muscle samples from captive leopard sharks.

\begin{tabular}{cccc}
\hline Shark ID & Experimental day & $\boldsymbol{\delta}^{\mathbf{1 3}} \mathbf{C}$ & $\boldsymbol{\delta}^{\mathbf{1 5}} \mathbf{N}$ \\
BL & 28 & -16.8 & 19.6 \\
BL & 42 & -17.9 & 18.2 \\
BL & 61 & -17.5 & 18.5 \\
BL & 87 & -17.3 & 17.6 \\
BL & 98 & -17.0 & 17.9 \\
BL & 112 & -17.2 & 17.7 \\
BL & 126 & -17.2 & 18.0 \\
BL & 140 & -17.4 & 17.0 \\
BL & 154 & -17.4 & 18.2 \\
BL & 168 & -16.8 & 17.0 \\
BL & 182 & -16.1 & 14.3 \\
BL & 196 & -16.9 & 15.5 \\
BL & 210 & -18.3 & 19.6 \\
BL & 239 & -16.7 & 17.9 \\
BL & 273 & -16.5 & 15.5 \\
BL & 308 & -17.2 & 16.9 \\
BL & 329 & -17.0 & 16.7 \\
BL & 400 & -17.0 & 17.0 \\
BL & 455 & -16.9 & 16.1 \\
BL & 475 & -16.4 & 15.4 \\
BL & 496 & -16.4 & 15.9 \\
BL & 591 & -17.8 & 15.8 \\
BL & 615 & -17.5 & 16.5 \\
BL & 633 & -18.2 & 15.2 \\
BL & 654 & -18.3 & 15.5 \\
BL & 665 & -20.3 & 13.1 \\
BL & 696 & -18.4 & 14.8 \\
BL & 749 & -19.5 & 14.0 \\
BL & 791 & -18.8 & 14.8 \\
BL & 833 & -18.7 & 15.3 \\
BL & 875 & -19.1 & 15.3 \\
BL & 917 & -19.4 & 15.1 \\
BL & 959 & -19.7 & 14.4 \\
BL & 997 & -21.1 & 12.9 \\
BL & 1039 & -19.7 & 14.4 \\
BL & 1090 & -20.4 & 14.6 \\
BL & 1131 & -21.4 & 12.5 \\
\hline
\end{tabular}




\begin{tabular}{|c|c|c|c|}
\hline Shark ID & Experimental day & $\delta^{13} \mathrm{C}$ & $\delta^{15} \mathrm{~N}$ \\
\hline $\mathrm{BL}$ & 1153 & -20.8 & 13.8 \\
\hline BL & 1174 & -21.3 & 12.4 \\
\hline BS & 28 & -12.2 & 5.6 \\
\hline BS & 42 & -18.3 & 19.4 \\
\hline $\mathrm{BS}$ & 61 & -16.1 & 19.1 \\
\hline $\mathrm{BS}$ & 94 & -17.4 & 18.1 \\
\hline $\mathrm{BS}$ & 98 & -17.5 & 18.5 \\
\hline BS & 112 & -17.7 & 18.1 \\
\hline $\mathrm{BS}$ & 126 & -17.7 & 18.5 \\
\hline $\mathrm{BS}$ & 140 & -17.6 & 17.9 \\
\hline $\mathrm{BS}$ & 168 & -42.1 & 17.3 \\
\hline BS & 182 & -17.6 & 16.9 \\
\hline $\mathrm{BS}$ & 196 & -17.2 & 16.3 \\
\hline BS & 210 & -17.4 & 17.8 \\
\hline $\mathrm{BS}$ & 239 & -16.9 & 16.9 \\
\hline $\mathrm{BS}$ & 273 & -17.6 & 16.5 \\
\hline BS & 308 & -17.6 & 16.9 \\
\hline $\mathrm{BS}$ & 329 & -17.0 & 16.5 \\
\hline $\mathrm{BS}$ & 400 & -17.0 & 16.2 \\
\hline $\mathrm{BS}$ & 455 & -17.0 & 15.9 \\
\hline $\mathrm{BS}$ & 475 & -16.9 & 15.4 \\
\hline $\mathrm{BS}$ & 496 & -16.5 & 15.9 \\
\hline $\mathrm{BS}$ & 591 & -17.1 & 16.0 \\
\hline $\mathrm{BS}$ & 615 & -17.5 & 16.3 \\
\hline $\mathrm{BS}$ & 633 & -18.2 & 15.9 \\
\hline BS & 654 & -19.0 & 14.6 \\
\hline BS & 665 & -18.0 & 16.5 \\
\hline BS & 696 & -18.6 & 15.1 \\
\hline $\mathrm{BS}$ & 749 & -18.6 & 15.1 \\
\hline BS & 791 & -19.4 & 14.7 \\
\hline BS & 833 & -19.5 & 14.0 \\
\hline $\mathrm{BS}$ & 875 & -19.1 & 14.9 \\
\hline BS & 917 & -20.6 & 13.0 \\
\hline BS & 959 & -19.8 & 14.4 \\
\hline BS & 997 & -21.0 & 12.1 \\
\hline BS & 1039 & -21.2 & 12.5 \\
\hline BS & 1090 & -21.7 & 13.1 \\
\hline $\mathrm{BS}$ & 1131 & -21.2 & 12.6 \\
\hline $\mathrm{BS}$ & 1153 & -21.0 & 13.3 \\
\hline BS & 1174 & -20.7 & 13.3 \\
\hline
\end{tabular}

Page $\mathbf{3}$ of $\mathbf{2 0}$ 


\begin{tabular}{|c|c|c|c|}
\hline Shark ID & Experimental day & $\delta^{13} \mathrm{C}$ & $\delta^{15} \mathbf{N}$ \\
\hline CS & 28 & -16.8 & 19.3 \\
\hline $\mathrm{CS}$ & 42 & -18.1 & 17.9 \\
\hline $\mathrm{CS}$ & 61 & -17.1 & 19.7 \\
\hline $\mathrm{CS}$ & 87 & -14.9 & 20.3 \\
\hline $\mathrm{CS}$ & 98 & -16.5 & 19.4 \\
\hline $\mathrm{CS}$ & 112 & -17.0 & 19.2 \\
\hline $\mathrm{CS}$ & 140 & -16.5 & 18.3 \\
\hline $\mathrm{CS}$ & 154 & -16.3 & 18.1 \\
\hline $\mathrm{CS}$ & 154 & -16.8 & 18.0 \\
\hline $\mathrm{CS}$ & 168 & -16.2 & 18.4 \\
\hline $\mathrm{CS}$ & 182 & -16.7 & 18.0 \\
\hline $\mathrm{CS}$ & 196 & -16.6 & 16.8 \\
\hline $\mathrm{CS}$ & 210 & -18.0 & 18.7 \\
\hline $\mathrm{CS}$ & 239 & -16.3 & 17.5 \\
\hline $\mathrm{CS}$ & 273 & -15.9 & 13.7 \\
\hline $\mathrm{CS}$ & 308 & -16.5 & 17.0 \\
\hline $\mathrm{CS}$ & 329 & -16.6 & 16.3 \\
\hline $\mathrm{CS}$ & 329 & -16.7 & 16.3 \\
\hline $\mathrm{CS}$ & 400 & -15.7 & 17.3 \\
\hline $\mathrm{CS}$ & 455 & -16.6 & 16.0 \\
\hline $\mathrm{CS}$ & 475 & -16.6 & 16.5 \\
\hline $\mathrm{CS}$ & 496 & -16.6 & 15.8 \\
\hline $\mathrm{CS}$ & 591 & -16.8 & 16.6 \\
\hline $\mathrm{CS}$ & 615 & -16.6 & 17.4 \\
\hline $\mathrm{CS}$ & 633 & -16.7 & 17.4 \\
\hline $\mathrm{CS}$ & 654 & -16.4 & 15.9 \\
\hline CS & 665 & -16.8 & 17.0 \\
\hline $\mathrm{CS}$ & 696 & -16.7 & 17.5 \\
\hline $\mathrm{CS}$ & 749 & -17.1 & 17.6 \\
\hline $\mathrm{CS}$ & 791 & -16.7 & 17.3 \\
\hline $\mathrm{CS}$ & 833 & -16.8 & 17.2 \\
\hline CS & 875 & -16.8 & 16.9 \\
\hline CS & 917 & -16.7 & 16.5 \\
\hline $\mathrm{CS}$ & 959 & -16.3 & 17.4 \\
\hline $\mathrm{CS}$ & 997 & -16.5 & 17.1 \\
\hline CS & 1039 & -16.7 & 17.2 \\
\hline $\mathrm{CS}$ & 1090 & -16.4 & 17.1 \\
\hline $\mathrm{CS}$ & 1131 & -16.7 & 16.5 \\
\hline DL & 54 & -16.8 & 17.7 \\
\hline DL & 94 & -16.6 & 18.5 \\
\hline
\end{tabular}

Page $\mathbf{4}$ of $\mathbf{2 0}$ 


\begin{tabular}{|c|c|c|c|}
\hline Shark ID & Experimental day & $\delta^{13} \mathrm{C}$ & $\delta^{15} \mathbf{N}$ \\
\hline DL & 94 & -16.8 & 18.4 \\
\hline DL & 105 & -16.4 & 17.7 \\
\hline DL & 119 & -16.9 & 17.1 \\
\hline $\mathrm{DL}$ & 133 & -16.8 & 18.0 \\
\hline $\mathrm{DL}$ & 161 & -16.7 & 17.3 \\
\hline $\mathrm{DL}$ & 175 & -16.6 & 18.7 \\
\hline DL & 189 & -16.5 & 16.6 \\
\hline DL & 203 & -16.6 & 14.5 \\
\hline DL & 231 & -15.9 & 17.9 \\
\hline DL & 267 & -16.3 & 16.9 \\
\hline DL & 301 & -16.4 & 17.8 \\
\hline $\mathrm{DL}$ & 357 & -16.9 & 16.5 \\
\hline DL & 392 & -16.7 & 16.9 \\
\hline DL & 420 & -14.2 & 18.1 \\
\hline DL & 435 & -17.1 & 17.2 \\
\hline DL & 475 & -15.9 & 16.3 \\
\hline DL & 496 & -16.6 & 16.7 \\
\hline DL & 591 & -16.9 & 16.1 \\
\hline DL & 615 & -17.8 & 15.2 \\
\hline DL & 633 & -18.2 & 14.9 \\
\hline DL & 654 & -18.2 & 14.9 \\
\hline DL & 665 & -18.1 & 15.6 \\
\hline DL & 696 & -18.2 & 15.3 \\
\hline DL & 749 & -18.0 & 16.0 \\
\hline DL & 791 & -19.6 & 13.8 \\
\hline DL & 875 & -17.9 & 15.7 \\
\hline DL & 917 & -18.2 & 15.3 \\
\hline DL & 959 & -18.9 & 14.8 \\
\hline $\mathrm{DL}$ & 997 & -20.0 & 13.3 \\
\hline $\mathrm{DL}$ & 1039 & -20.2 & 13.8 \\
\hline $\mathrm{DL}$ & 1090 & -19.9 & 14.2 \\
\hline $\mathrm{DL}$ & 1131 & -19.4 & 14.4 \\
\hline $\mathrm{DL}$ & 1153 & -19.9 & 13.8 \\
\hline DL & 1174 & -19.5 & 14.1 \\
\hline DS & 54 & -16.1 & 21.2 \\
\hline DS & 94 & -17.1 & 21.5 \\
\hline DS & 105 & -17.1 & 21.1 \\
\hline DS & 119 & -17.4 & 20.5 \\
\hline DS & 126 & -17.3 & 19.0 \\
\hline DS & 133 & -17.5 & 20.9 \\
\hline
\end{tabular}

Page $\mathbf{5}$ of $\mathbf{2 0}$ 


\begin{tabular}{|c|c|c|c|}
\hline Shark ID & Experimental day & $\delta^{13} \mathrm{C}$ & $\delta^{15} \mathbf{N}$ \\
\hline DS & 146 & -17.4 & 20.5 \\
\hline DS & 161 & -17.3 & 19.3 \\
\hline DS & 175 & -16.4 & 17.3 \\
\hline DS & 189 & -16.6 & 17.7 \\
\hline DS & 203 & -17.1 & 18.4 \\
\hline DS & 231 & -16.7 & 18.0 \\
\hline DS & 267 & -16.5 & 18.7 \\
\hline DS & 301 & -16.5 & 15.7 \\
\hline DS & 322 & -16.7 & 16.2 \\
\hline DS & 357 & -17.0 & 18.4 \\
\hline DS & 392 & -16.6 & 18.0 \\
\hline DS & 420 & -15.6 & 16.2 \\
\hline DS & 435 & -17.0 & 21.5 \\
\hline DS & 475 & -16.7 & 15.7 \\
\hline DS & 496 & -16.4 & 15.6 \\
\hline DS & 591 & -16.8 & 17.7 \\
\hline DS & 615 & -17.2 & 17.1 \\
\hline DS & 633 & -17.3 & 17.1 \\
\hline DS & 654 & -17.8 & 16.4 \\
\hline DS & 665 & -17.8 & 17.2 \\
\hline DS & 696 & -18.3 & 15.4 \\
\hline DS & 749 & -18.1 & 16.5 \\
\hline DS & 791 & -19.8 & 13.6 \\
\hline DS & 833 & -18.5 & 17.6 \\
\hline DS & 875 & -19.5 & 14.5 \\
\hline DS & 917 & -20.1 & 13.7 \\
\hline DS & 959 & -19.8 & 13.6 \\
\hline DS & 997 & -20.3 & 13.3 \\
\hline DS & 1039 & -20.4 & 13.5 \\
\hline DS & 1090 & -20.4 & 13.7 \\
\hline DS & 1131 & -20.6 & 13.9 \\
\hline DS & 1153 & -21.2 & 12.8 \\
\hline DS & 1174 & -20.5 & 13.6 \\
\hline EL & 54 & -17.8 & 19.2 \\
\hline EL & 94 & -16.6 & 19.3 \\
\hline EL & 119 & -17.4 & 17.4 \\
\hline EL & 161 & -16.9 & 17.5 \\
\hline EL & 175 & -17.6 & 18.7 \\
\hline EL & 189 & -17.2 & 16.2 \\
\hline EL & 203 & -17.1 & 16.1 \\
\hline
\end{tabular}

Page $\mathbf{6}$ of $\mathbf{2 0}$ 


\begin{tabular}{|c|c|c|c|}
\hline Shark ID & Experimental day & $\delta^{13} \mathrm{C}$ & $\delta^{15} \mathbf{N}$ \\
\hline EL & 231 & -16.6 & 16.7 \\
\hline EL & 267 & -15.9 & 18.2 \\
\hline EL & 301 & -16.8 & 15.8 \\
\hline EL & 322 & -16.6 & 15.9 \\
\hline EL & 357 & -17.2 & 18.4 \\
\hline EL & 392 & -16.7 & 16.1 \\
\hline EL & 420 & -16.2 & 15.7 \\
\hline EL & 435 & -17.6 & 18.4 \\
\hline EL & 475 & -15.8 & 16.6 \\
\hline EL & 503 & -16.6 & 16.1 \\
\hline EL & 591 & -16.8 & 15.8 \\
\hline EL & 615 & -17.1 & 16.1 \\
\hline EL & 633 & -17.5 & 15.3 \\
\hline EL & 654 & -17.6 & 15.2 \\
\hline EL & 665 & -18.0 & 15.3 \\
\hline EL & 696 & -17.8 & 15.1 \\
\hline EL & 749 & -17.9 & 15.4 \\
\hline EL & 791 & -17.8 & 15.2 \\
\hline EL & 833 & -18.3 & 14.6 \\
\hline EL & 875 & -16.6 & 16.7 \\
\hline EL & 917 & -18.0 & 15.3 \\
\hline EL & 959 & -19.3 & 13.5 \\
\hline EL & 997 & -19.2 & 13.8 \\
\hline EL & 1039 & -20.7 & 12.7 \\
\hline EL & 1090 & -19.5 & 14.3 \\
\hline EL & 1131 & -19.7 & 13.5 \\
\hline EL & 1153 & -19.1 & 14.2 \\
\hline EL & 1174 & -19.9 & 13.1 \\
\hline ES & 54 & -16.3 & 17.4 \\
\hline ES & 94 & -16.1 & 17.6 \\
\hline $\mathrm{ES}$ & 105 & -16.3 & 17.2 \\
\hline ES & 119 & -16.4 & 16.2 \\
\hline ES & 133 & -16.6 & 17.4 \\
\hline ES & 146 & -16.4 & 17.4 \\
\hline ES & 161 & -16.1 & 16.7 \\
\hline $\mathrm{ES}$ & 175 & -16.8 & 19.8 \\
\hline ES & 189 & -16.2 & 16.1 \\
\hline ES & 203 & -16.1 & 15.9 \\
\hline ES & 231 & -36.5 & 14.0 \\
\hline ES & 267 & -16.2 & 16.1 \\
\hline
\end{tabular}




\begin{tabular}{|c|c|c|c|}
\hline Shark ID & Experimental day & $\delta^{13} \mathrm{C}$ & $\delta^{15} \mathbf{N}$ \\
\hline ES & 301 & -17.0 & 16.4 \\
\hline ES & 322 & -16.7 & 16.4 \\
\hline $\mathrm{ES}$ & 357 & -16.7 & 16.1 \\
\hline ES & 392 & -16.3 & 16.4 \\
\hline ES & 420 & -16.4 & 15.7 \\
\hline ES & 435 & -16.6 & 16.4 \\
\hline ES & 475 & -16.5 & 16.0 \\
\hline ES & 503 & -16.2 & 15.3 \\
\hline ES & 591 & -16.8 & 16.1 \\
\hline ES & 615 & -17.4 & 15.5 \\
\hline ES & 633 & -17.5 & 15.2 \\
\hline $\mathrm{ES}$ & 654 & -17.2 & 15.9 \\
\hline $\mathrm{ES}$ & 665 & -17.4 & 16.0 \\
\hline ES & 696 & -17.4 & 15.8 \\
\hline ES & 749 & -17.5 & 15.5 \\
\hline ES & 791 & -18.4 & 15.2 \\
\hline ES & 833 & -18.0 & 15.2 \\
\hline ES & 875 & -18.0 & 15.7 \\
\hline ES & 917 & -17.5 & 15.3 \\
\hline ES & 959 & -18.5 & 14.4 \\
\hline ES & 997 & -18.7 & 14.3 \\
\hline $\mathrm{ES}$ & 1039 & -19.2 & 14.0 \\
\hline ES & 1090 & -19.7 & 14.1 \\
\hline $\mathrm{ES}$ & 1131 & -19.2 & 14.1 \\
\hline ES & 1153 & -20.0 & 13.2 \\
\hline $\mathrm{ES}$ & 1174 & -20.3 & 12.8 \\
\hline FL & 54 & -17.2 & 19.6 \\
\hline FL & 94 & -17.3 & 19.8 \\
\hline FL & 105 & -17.1 & 17.8 \\
\hline FL & 133 & -17.7 & 20.4 \\
\hline FL & 161 & -17.5 & 18.3 \\
\hline FL & 175 & -17.4 & 18.2 \\
\hline $\mathrm{FL}$ & 189 & -17.5 & 17.5 \\
\hline FL & 203 & -17.3 & 16.7 \\
\hline FL & 231 & -17.7 & 18.2 \\
\hline $\mathrm{FL}$ & 267 & -16.4 & 15.4 \\
\hline FL & 301 & -16.9 & 16.5 \\
\hline FL & 322 & -16.6 & 15.9 \\
\hline $\mathrm{FL}$ & 357 & -17.2 & 16.9 \\
\hline $\mathrm{FL}$ & 392 & -16.9 & 16.4 \\
\hline
\end{tabular}

Page $\mathbf{8}$ of $\mathbf{2 0}$ 


\begin{tabular}{|c|c|c|c|}
\hline Shark ID & Experimental day & $\delta^{13} \mathrm{C}$ & $\delta^{15} \mathrm{~N}$ \\
\hline FL & 420 & -16.1 & 15.6 \\
\hline FL & 435 & -17.8 & 19.8 \\
\hline FL & 475 & -16.6 & 16.4 \\
\hline FL & 503 & -16.4 & 16.0 \\
\hline FL & 591 & -16.8 & 17.1 \\
\hline $\mathrm{FL}$ & 615 & -16.8 & 17.3 \\
\hline FL & 633 & -17.0 & 17.4 \\
\hline FL & 654 & -16.9 & 17.2 \\
\hline $\mathrm{FL}$ & 665 & -16.9 & 17.6 \\
\hline $\mathrm{FL}$ & 696 & -16.6 & 18.0 \\
\hline FL & 749 & -16.9 & 17.9 \\
\hline FL & 791 & -16.6 & 17.0 \\
\hline FL & 833 & -16.7 & 16.7 \\
\hline $\mathrm{FL}$ & 875 & -16.8 & 17.6 \\
\hline FL & 917 & -16.7 & 17.2 \\
\hline FL & 959 & -16.7 & 17.6 \\
\hline FL & 997 & -16.7 & 17.5 \\
\hline FL & 1039 & -16.6 & 17.3 \\
\hline FS & 54 & -17.4 & 19.0 \\
\hline $\mathrm{FS}$ & 94 & -17.4 & 19.6 \\
\hline FS & 119 & -17.2 & 18.4 \\
\hline $\mathrm{FS}$ & 133 & -17.3 & 18.6 \\
\hline FS & 161 & -17.0 & 17.9 \\
\hline $\mathrm{FS}$ & 175 & -16.9 & 17.9 \\
\hline $\mathrm{FS}$ & 189 & -16.4 & 17.1 \\
\hline FS & 203 & -17.2 & 16.6 \\
\hline $\mathrm{FS}$ & 231 & -16.8 & 16.6 \\
\hline FS & 267 & -16.2 & 16.2 \\
\hline $\mathrm{FS}$ & 301 & -17.0 & 16.4 \\
\hline $\mathrm{FS}$ & 322 & -16.4 & 15.6 \\
\hline $\mathrm{FS}$ & 357 & -17.2 & 17.2 \\
\hline FS & 392 & -16.1 & 16.3 \\
\hline $\mathrm{FS}$ & 420 & -16.4 & 15.9 \\
\hline FS & 435 & -17.1 & 18.8 \\
\hline FS & 475 & -17.1 & 16.9 \\
\hline $\mathrm{FS}$ & 503 & -16.2 & 15.6 \\
\hline $\mathrm{FS}$ & 591 & -16.7 & 16.4 \\
\hline $\mathrm{FS}$ & 615 & -16.6 & 16.6 \\
\hline FS & 633 & -16.8 & 17.0 \\
\hline $\mathrm{FS}$ & 654 & -17.0 & 17.3 \\
\hline
\end{tabular}

Page $\mathbf{9}$ of $\mathbf{2 0}$ 


\begin{tabular}{cccc}
\hline Shark ID & Experimental day & $\boldsymbol{\delta}^{\mathbf{1 3}} \mathbf{C}$ & $\boldsymbol{\delta}^{\mathbf{1 5}} \mathbf{N}$ \\
FS & 665 & -16.9 & 17.2 \\
FS & 696 & -17.0 & 16.8 \\
FS & 749 & -16.9 & 16.8 \\
FS & 791 & -16.6 & 16.9 \\
FS & 833 & -17.0 & 16.6 \\
FS & 875 & -15.9 & 17.0 \\
FS & 917 & -16.7 & 17.2 \\
FS & 959 & -16.5 & 16.8 \\
FS & 997 & -16.4 & 16.9 \\
FS & 1039 & -16.5 & 17.0 \\
FS & 1131 & -16.7 & 16.4 \\
\hline
\end{tabular}


Table S2. Statistics ( $\mathrm{DF}=$ degrees of freedom) for one-tailed t-tests of whether stable isotope discrimination factors $\left(\Delta_{\text {shark muscle-diet }}\right)$ for captive leopard sharks differed from $0 \%$. Sharks were either fed squid for 1250 days (control group), or squid then tilapia as of day 565 (experimental group).

\begin{tabular}{|c|c|c|c|c|c|}
\hline & Amino acid & Group & $P$ & $\mathbf{t}$ & DF \\
\hline \multirow{24}{*}{$\Delta^{13} \mathrm{C}$} & Alanine & Control & 0.049 & 2.956 & 2 \\
\hline & Alanine & Experimental & $<0.001$ & 9.902 & 5 \\
\hline & Glycine & Control & 0.041 & 3.275 & 2 \\
\hline & Glycine & Experimental & $<0.001$ & 11.539 & 5 \\
\hline & Threonine & Control & 0.123 & 1.619 & 2 \\
\hline & Threonine & Experimental & 0.142 & 1.021 & 5 \\
\hline & Serine & Control & 0.316 & -0.561 & 2 \\
\hline & Serine & Experimental & 0.294 & 0.579 & 5 \\
\hline & Valine & Control & 0.026 & 4.175 & 2 \\
\hline & Valine & Experimental & $<0.001$ & 10.974 & 5 \\
\hline & Leucine & Control & 0.019 & 4.942 & 2 \\
\hline & Leucine & Experimental & $<0.001$ & 13.358 & 5 \\
\hline & Isoleucine & Control & 0.007 & 8.325 & 2 \\
\hline & Isoleucine & Experimental & $<0.001$ & 7.510 & 5 \\
\hline & Aspartic acid & Control & 0.013 & 5.984 & 2 \\
\hline & Aspartic acid & Experimental & $<0.001$ & 15.745 & 5 \\
\hline & Glutamic acid & Control & 0.008 & 7.879 & 2 \\
\hline & Glutamic acid & Experimental & $<0.001$ & 12.513 & 5 \\
\hline & Phenylalanine & Control & 0.078 & 2.228 & 2 \\
\hline & Phenylalanine & Experimental & $<0.001$ & 7.554 & 5 \\
\hline & Tyrosine & Control & 0.040 & 3.318 & 2 \\
\hline & Tyrosine & Experimental & $<0.001$ & 11.882 & 5 \\
\hline & Lysine & Control & 0.114 & 1.721 & 2 \\
\hline & Lysine & Experimental & $<0.001$ & 8.995 & 5 \\
\hline \multirow{16}{*}{$\Delta^{15} \mathrm{~N}$} & Alanine & Control & 0.026 & 4.201 & 2 \\
\hline & Alanine & Experimental & $<0.001$ & 19.247 & 5 \\
\hline & Glycine & Control & 0.045 & 3.120 & 2 \\
\hline & Glycine & Experimental & 0.020 & 2.752 & 5 \\
\hline & Threonine & Control & 0.012 & -6.426 & 2 \\
\hline & Threonine & Experimental & $<0.001$ & -37.709 & 5 \\
\hline & Serine & Control & 0.017 & -5.355 & 2 \\
\hline & Serine & Experimental & 0.038 & 2.225 & 5 \\
\hline & Valine & Control & 0.004 & 10.842 & 2 \\
\hline & Valine & Experimental & $<0.001$ & 21.664 & 5 \\
\hline & Leucine & Control & 0.005 & 10.033 & 2 \\
\hline & Leucine & Experimental & 0.005 & 10.033 & 5 \\
\hline & Isoleucine & Control & 0.001 & 20.349 & 2 \\
\hline & Isoleucine & Experimental & $<0.001$ & 30.074 & 5 \\
\hline & Aspartic acid & Control & 0.030 & 3.869 & 2 \\
\hline & Aspartic acid & Experimental & $<0.001$ & 21.011 & 5 \\
\hline
\end{tabular}




\begin{tabular}{llllll}
\hline & Amino acid & Group & $\boldsymbol{P}$ & t & DF \\
\hline \multirow{4}{*}{$\Delta^{15} \mathrm{~N}$} & Glutamic acid & Control & 0.007 & 8.668 & 2 \\
& Glutamic acid & Experimental & $<0.001$ & 19.147 & 4 \\
& Phenylalanine & Control & 0.171 & 1.236 & 2 \\
& Phenylalanine & Experimental & 0.484 & 0.414 & 5 \\
& Tyrosine & Control & 0.010 & 6.937 & 2 \\
& Tyrosine & Experimental & 0.021 & 2.699 & 5 \\
& Lysine & Control & 0.014 & 5.863 & 2 \\
Lysine & Experimental & 0.002 & 4.816 & 5 \\
\hline
\end{tabular}


Table S3. Statistics $(\mathrm{DF}=$ degrees of freedom) for two-tailed t-tests of whether stable isotope discrimination factors ( $\left.\Delta_{\text {shark muscle-diet }}\right)$ for captive leopard sharks differed between a control group and experimental group. The control group was fed squid for 1250 days and the experimental group was fed squid then tilapia as of day 565 .

\begin{tabular}{lllll}
\hline & Amino acid & $\boldsymbol{P}$ & $\mathbf{t}$ & $\mathbf{D F}$ \\
\hline Alanine & 0.056 & -2.289 & 7 \\
Glycine & 0.015 & -3.190 & 7 \\
Threonine & 0.971 & -0.038 & 7 \\
Serine & 0.535 & -0.652 & 7 \\
Valine & $0.381^{\mathrm{a}}$ & $11.000^{\mathrm{a}}$ & $\mathrm{NA}^{\mathrm{a}}$ \\
$\Delta^{13} \mathrm{C}$ & Leucine & 0.149 & -1.619 & 7 \\
& Isoleucine & 0.045 & -2.431 & 7 \\
Aspartic acid & 0.753 & 0.327 & 7 \\
Glutamic acid & 0.488 & 0.731 & 7 \\
Phenylalanine & 0.003 & -3.844 & 7 \\
Tyrosine & 0.069 & -2.144 & 7 \\
Lysine & 0.008 & -3.691 & 7 \\
\hline Alanine & $<0.001$ & -9.046 & 7 \\
Glycine & 0.496 & 0.719 & 7 \\
Threonine & 0.001 & 5.257 & 7 \\
Serine & 0.002 & -4.672 & 7 \\
Valine & $<0.001$ & -6.291 & 7 \\
$\Delta^{15} \mathrm{~N}$ & Leucine & $<0.001$ & -14.119 & 7 \\
Isoleucine & $<0.001$ & -10.691 & 7 \\
Aspartic acid & $<0.001$ & -7.663 & 7 \\
Glutamic acid & $<0.001$ & -9.186 & 6 \\
Phenylalanine & 0.397 & 0.902 & 7 \\
Tyrosine & 0.890 & -0.143 & 7 \\
Lysine & .107 & 1.849 & 7 \\
\hline
\end{tabular}

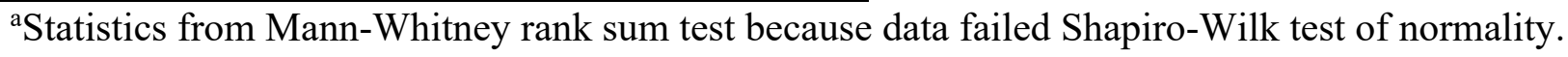


Figure S1. Data from six leopard sharks (individuals identified by a two-letter code) used in this captive feeding study. Measurements include body length (solid black line and circles) and stable isotope values of bulk muscle tissue $\left(\delta^{13} \mathrm{C}\right.$ values are black dashed line and circles, $\delta^{15} \mathrm{~N}$ values are dashed gray line and circles). Sharks were switched from a squid diet to a tilapia diet on 01August-2007. Also shown is temperature (thin black line) of seawater in Monterey Bay, California, USA, which was circulated in the shark tanks. Water temperature was measured in the bay at 2 meters below mean lower low water (MLLW) by the National Oceanic and Atmospheric Administration (sensor 9413450, data from https://tidesandcurrents.noaa.gov/). Shark data are reproduced from Kim et al. (2012).

\section{Reference}

Kim SL, Martínez del Rio C, Casper D, Koch PL. 2012. Isotopic incorporation rates for shark tissues from a long-term captive feeding study. Journal of Experimental Biology 215:2495-2500.

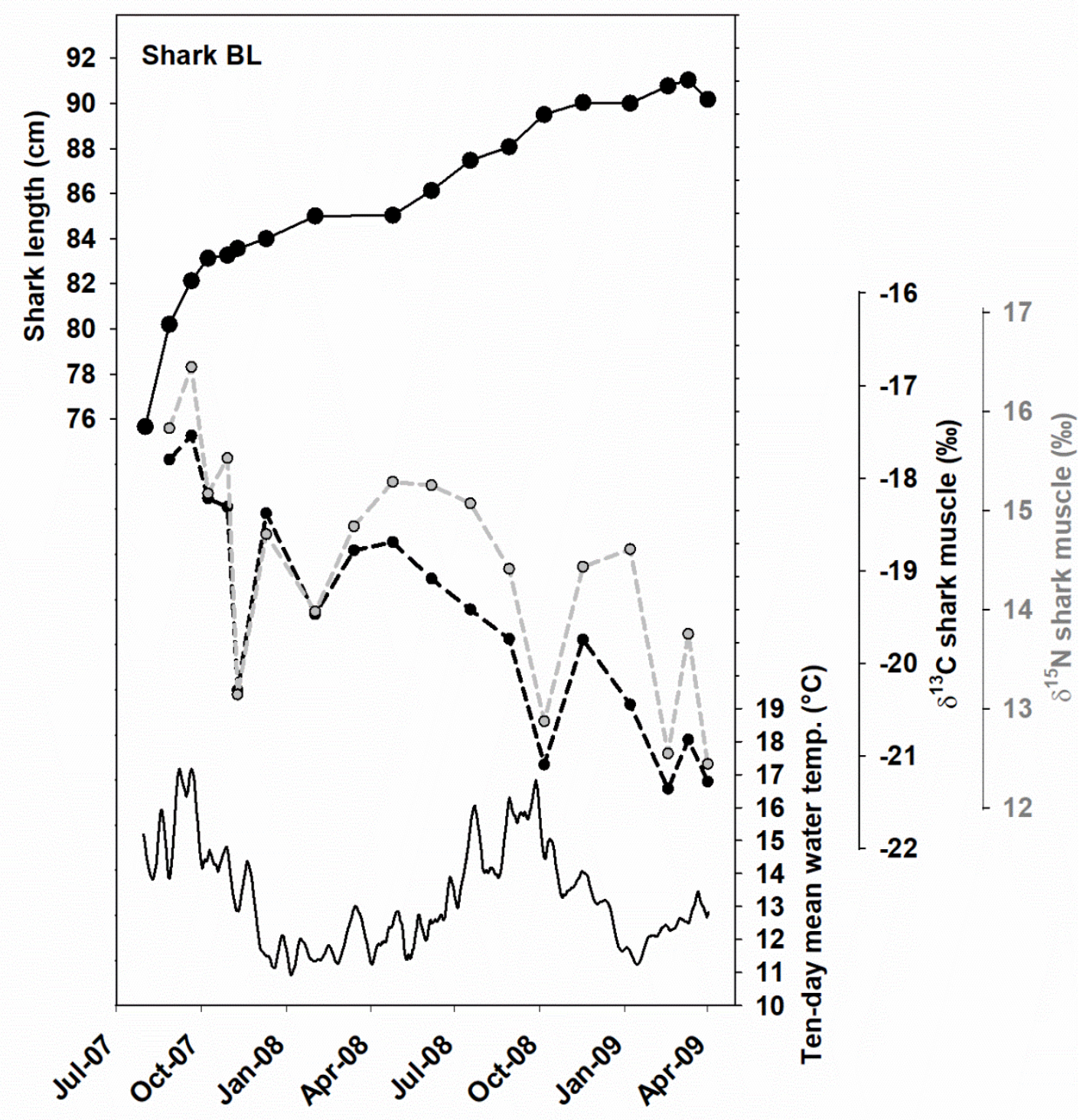




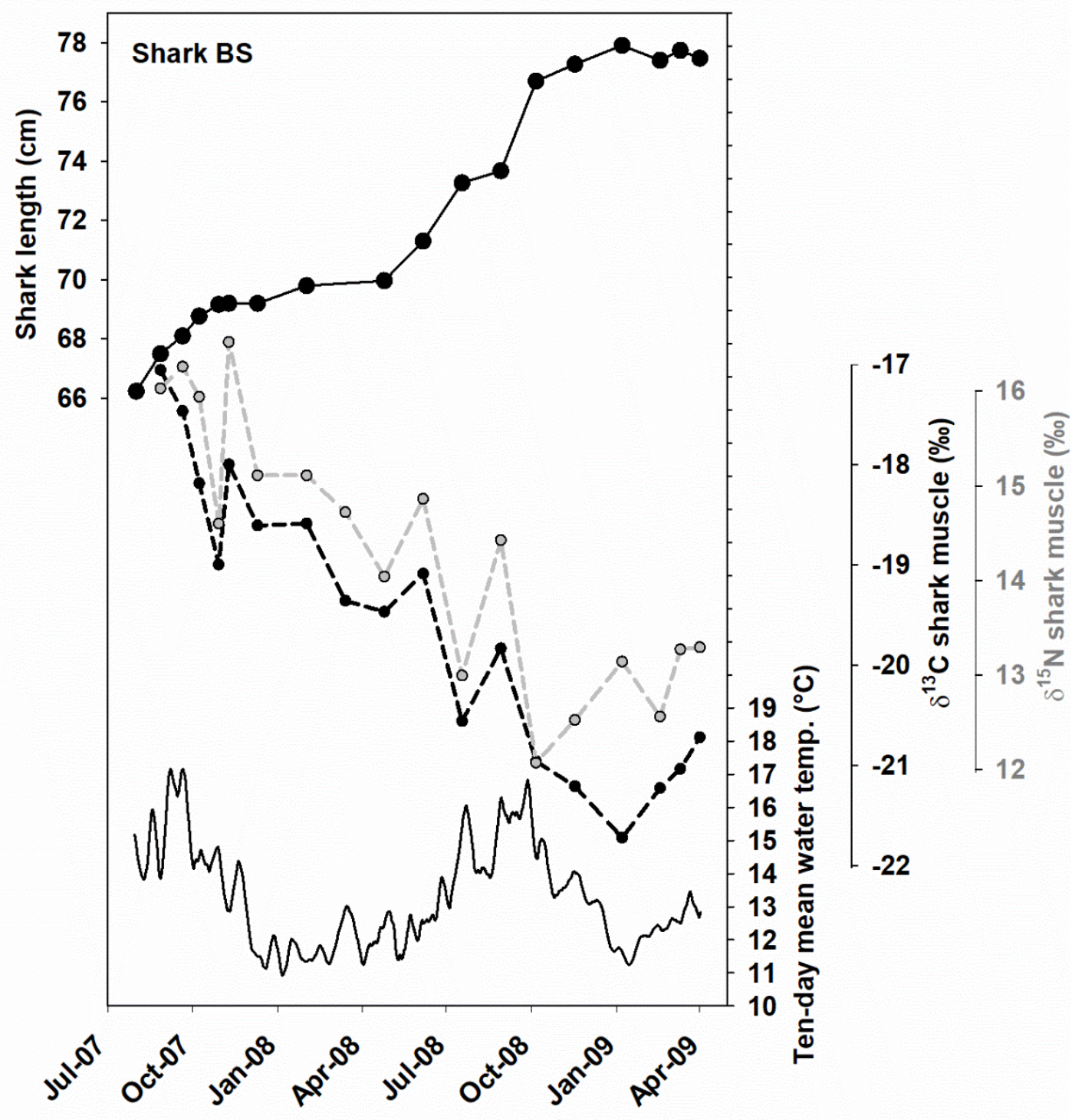




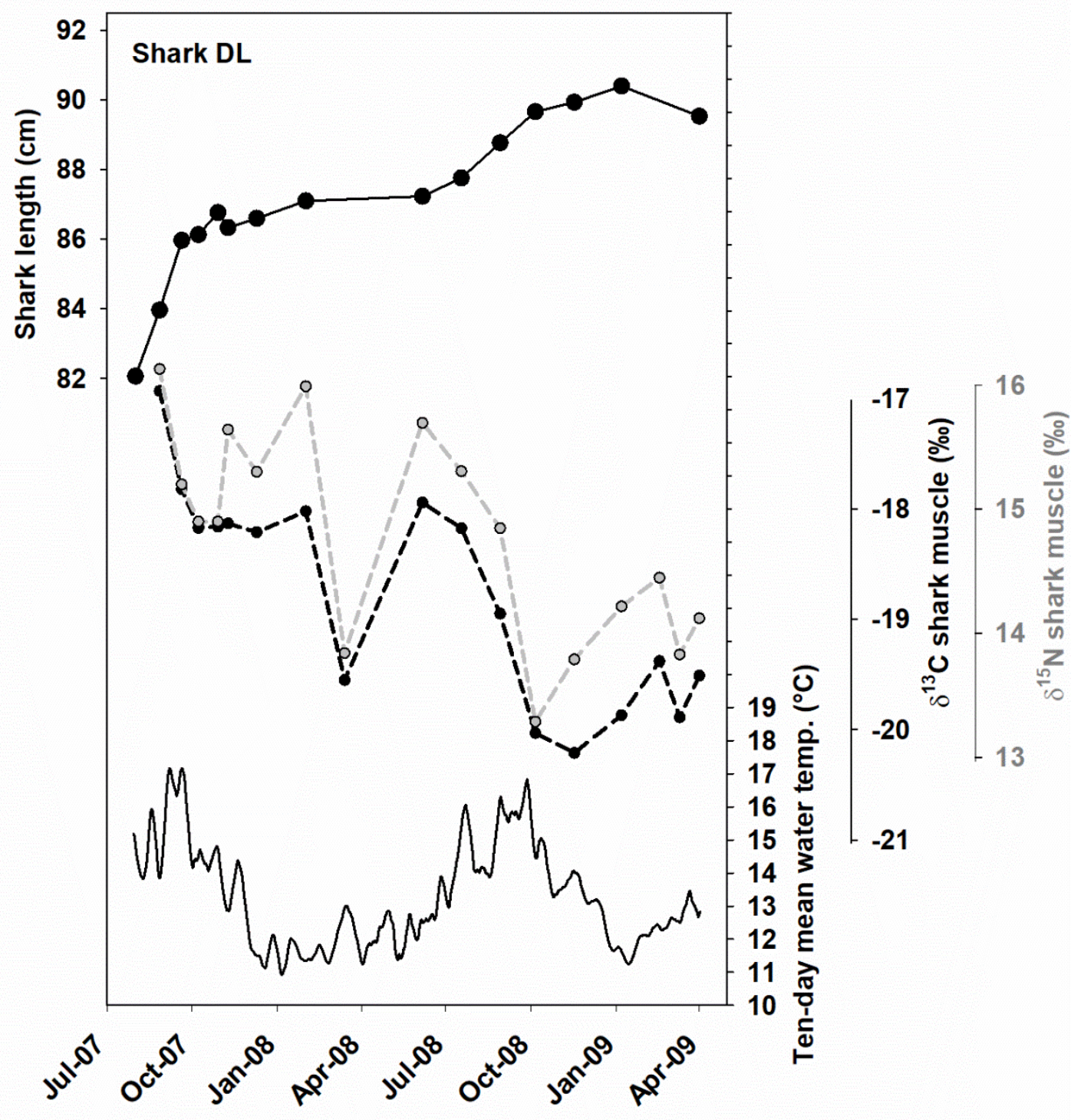




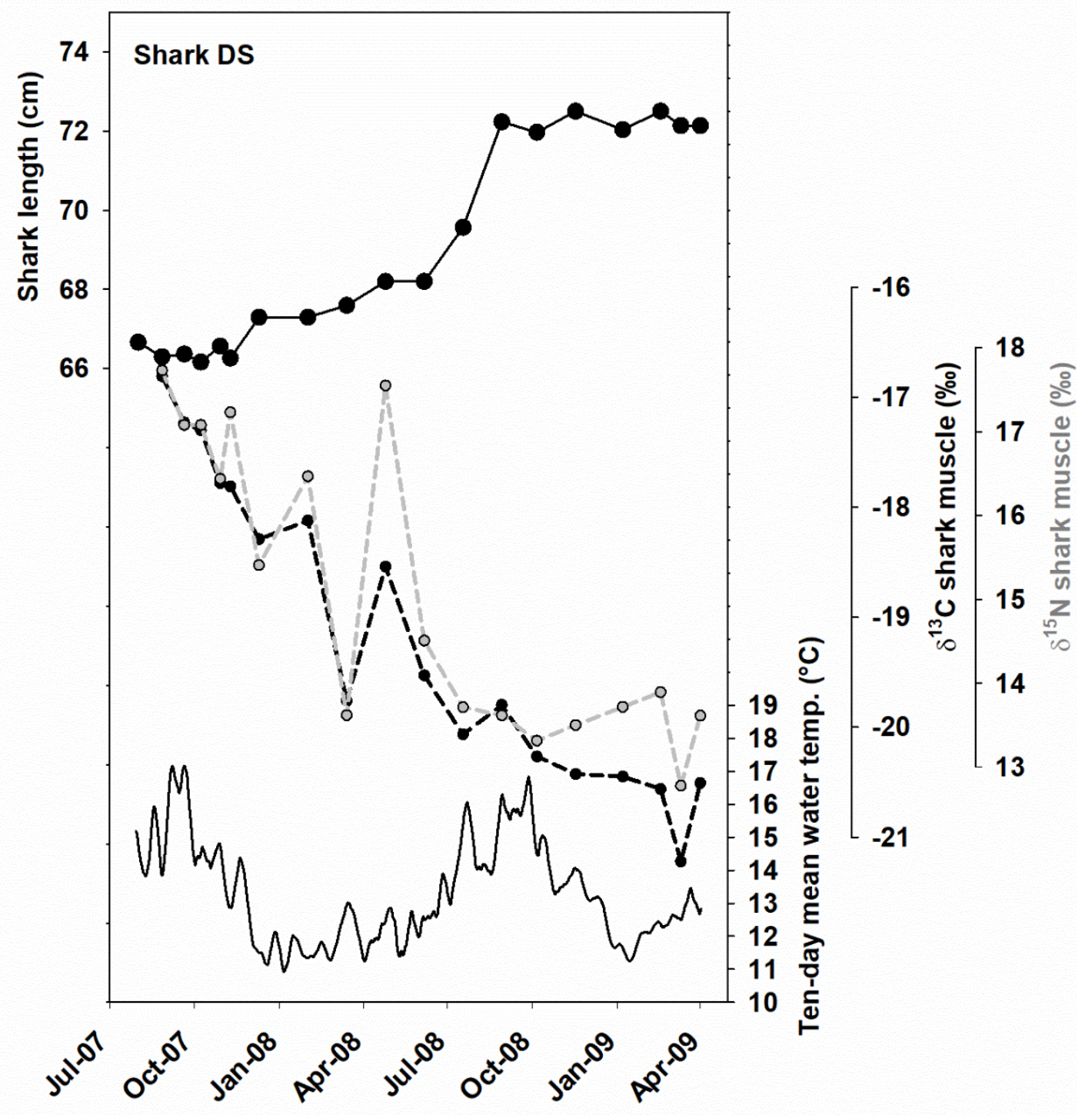




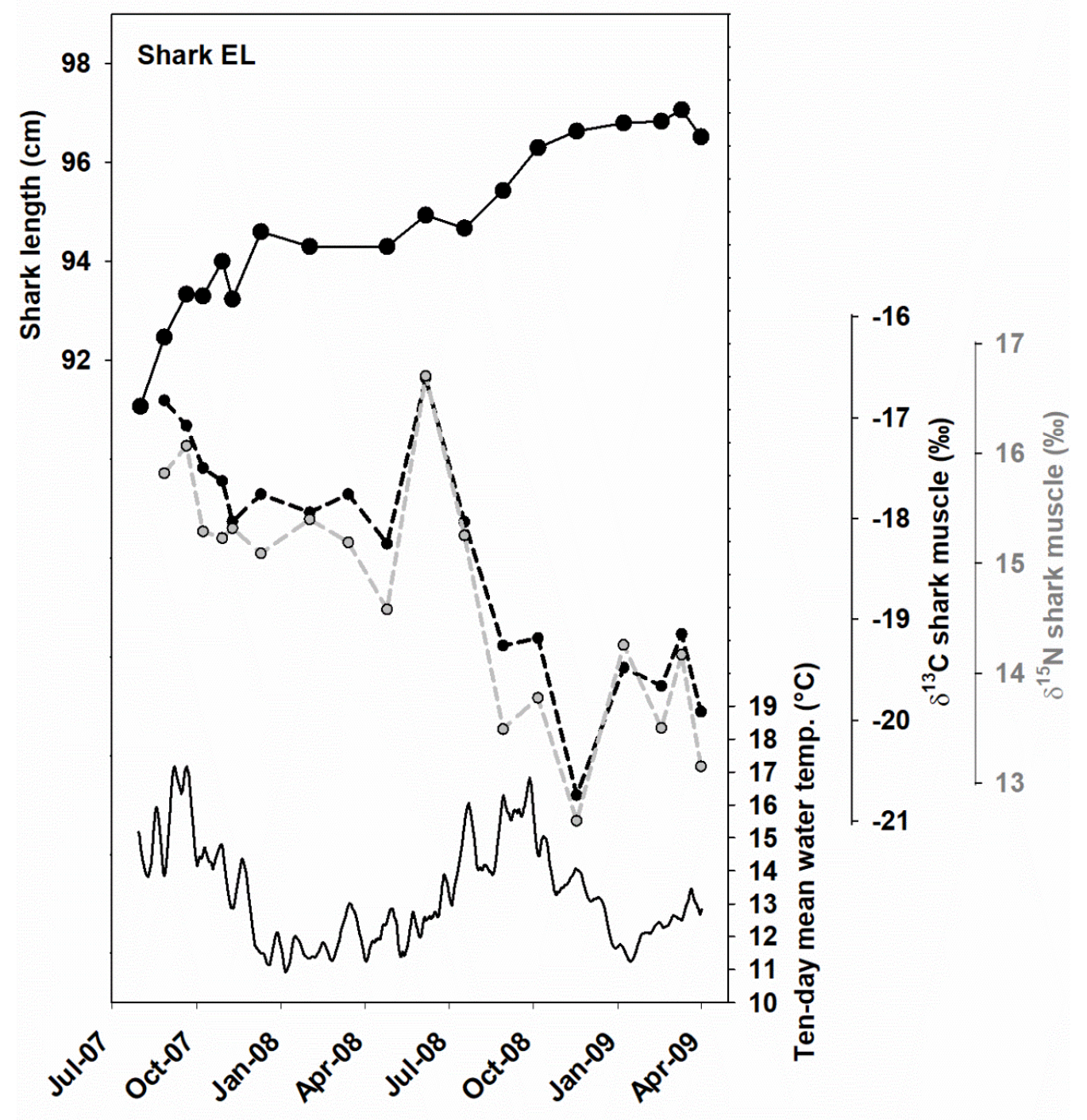




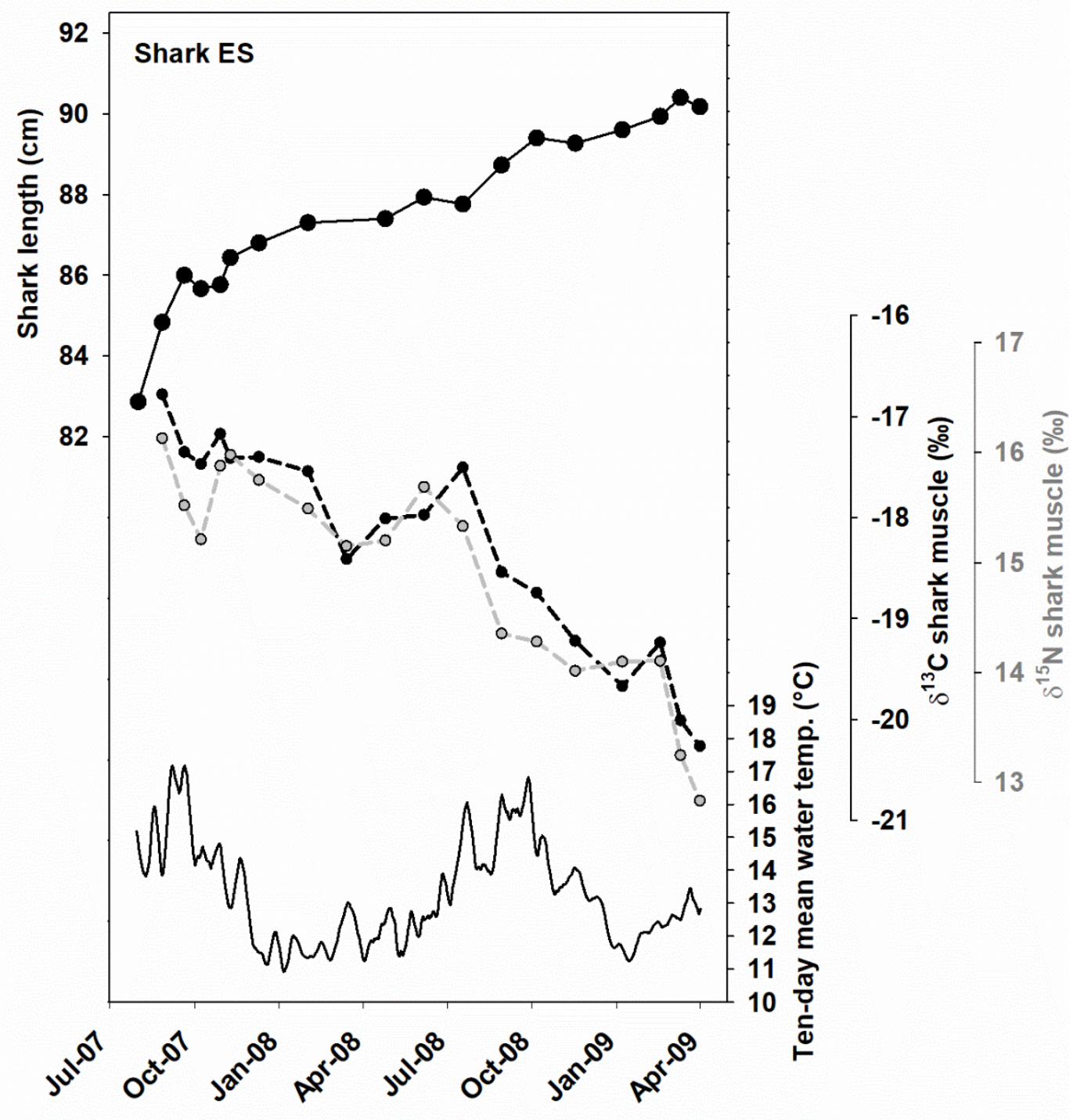

Page 19 of 20 
Figure S2. Consumer-diet discrimination factors for stable nitrogen isotopes $\left(\Delta^{15} N\right)$ of leopard sharks consuming squid, as measured in this study and as measured in Hoen et al. (2014). Box plots indicate median (solid line) and $25^{\text {th }}, 10^{\text {th }}$, and $5^{\text {th }}$ percentiles.

\section{Reference}

Hoen DK, Kim SL, Hussey NE, Wallsgrove NJ, Drazen JC, Popp BN. 2014. Amino acid ${ }^{15} \mathrm{~N}$ enrichment factors of four large carnivorous fishes. Journal of Experimental Marine Biology and Ecology 453:76-83.

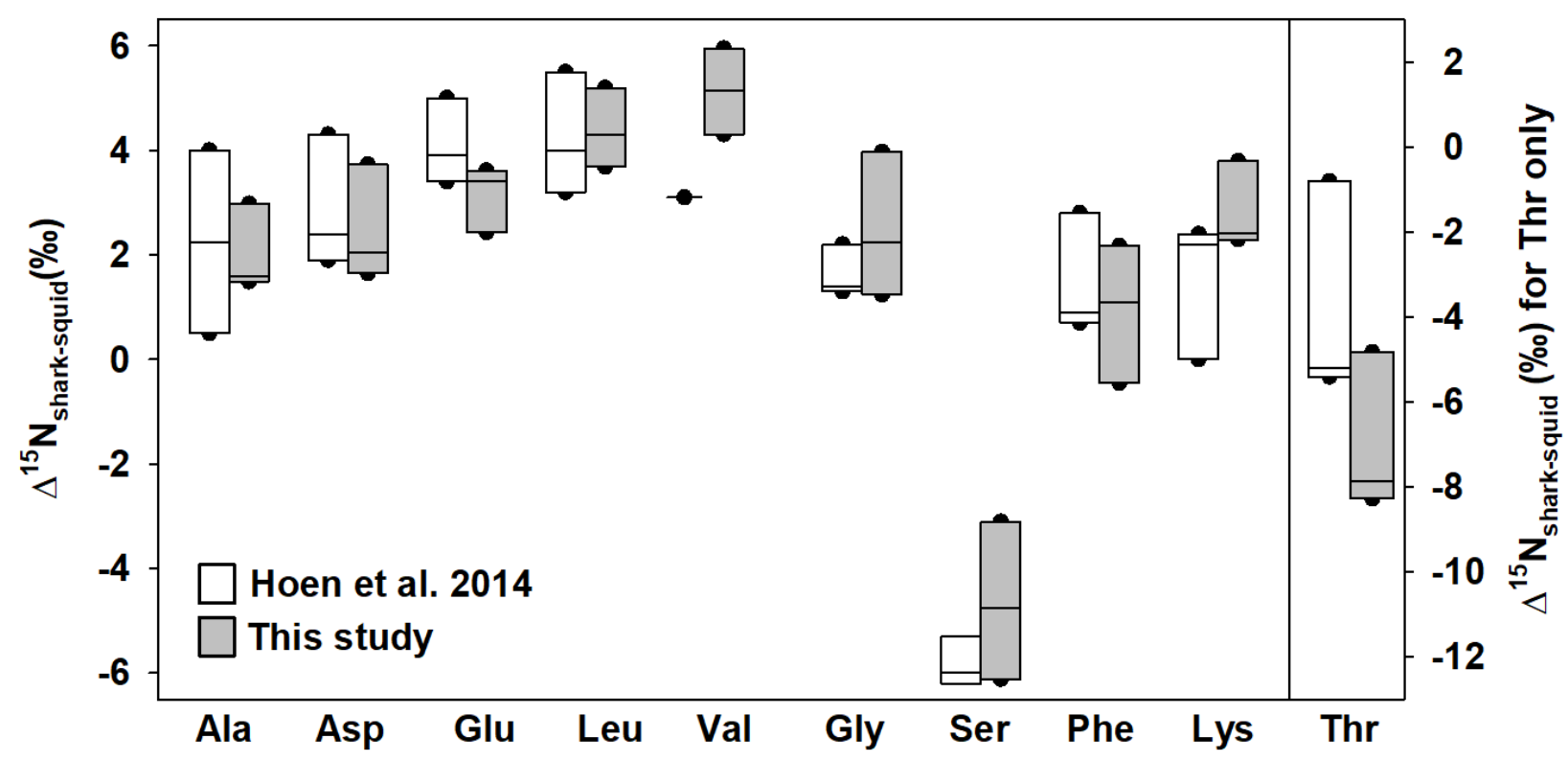

